\title{
ipen
}

INSTITUTO DE PESQUISAS ENERGÉTICAS E NUCLEARES

Autarquia Associada à Universidade de São Paulo

\section{APLICAÇÃO DA RADIAÇÃO DE FEIXE DE ELÉTRONS COMO PRÉ-TRATAMENTO DO BAGAÇO DA CANA-DE-AÇÚCAR PARA HIDRÓLISE ENZIMÁTICA DA CELULOSE}

\section{VANESSA MIGUEL CARDOSO}

Dissertação apresentada como parte dos requisitos para obtenção do Grau de Mestre em Ciências na Área de Tecnologia Nuclear - Aplicações.

Orientadora:

Dra. Celina Lopes Duarte

\section{SÃO PAULO}


Ao meu marido Vanderlei

À minha filha Angélica

Aos meus pais Lourisvaldo e Geni

Aos meus irmãos Viviane e Bruno 


\section{AGRADECIMENTOS}

À Dra.Celina Lopes Duarte, orientadora deste trabalho, pela oportunidade, paciência e apoio a mim oferecidos;

Ao Instituto de Pesquisas Energéticas e Nucleares, na pessoa do exSuperintendente Dr.Cláudio Rodrigues e atual Dr. Nilson Vieira Dias, pela oportunidade oferecida para o desenvolvimento do trabalho;

À Fundação de Amparo à Pesquisa do estado de São Paulo, FAPESP (projeto 2007/05679-0) e à Agência Internacional de Energia Atômica, AIEA (Research Contract In. 14709);

Ao Eng. Jaime Finguerut do Centro de Tecnologia Canavieira, CTC, pelo apoio ao trabalho e facilitação na coleta de amostras de bagaço;

À Dra. Célia Maria Araujo Galvão do CTC, pela realização e discussão das análises de hidrólise enzimática;

Ao colega Manuel Nunes Mori, agradecimento especial, pelo seu apoio nos experimentos deste trabalho;

À minha amiga Débora, por todos os favores a mim concedidos;

Aos colegas Hiroshi Oikawa e Hélio Rissei Nagatomy pelo apoio e tempo desprendido durante este trabalho;

À Dra. Áurea Beatriz C. Geraldo do Centro de Radiofarmácia e ao colega Eduardo do Centro de Biotecnologia pela considerável colaboração nas análises de FTIR e microscopia eletrônica;

Aos colegas Celso e Nildemar do Centro de Ciência e Tecnologia dos Materiais, pelo apoio concedido nas análises de microscopia eletrônica;

Ao meu marido Vanderlei por toda sua compreensão e apoio aos meus estudos, pela realização deste trabalho;

Aos colegas e funcionários desta Instituição que direta e indiretamente contribuíram para a realização deste trabalho. 


\title{
APLICAÇÃO DA RADIAÇÃO DE FEIXE DE ELÉTRONS COMO PRÉ-TRATAMENTO DO BAGAÇO DA CANA-DE-AÇÚCAR PARA HIDRÓLISE ENZIMÁTICA DA CELULOSE
}

\author{
Vanessa Miguel Cardoso \\ RESUMO
}

A escassez mundial de alimento e fontes de energia tem levado ao interesse de utilização de fontes de biomassa, desse modo o bagaço de canade-açúcar tem sido considerado para ração animal e produção de energia renovável. O bagaço da cana-de-açúcar geralmente contém cerca de $40 \%$ de celulose, cerca de $40 \%$ de hemicelulose e cerca de $20 \%$ de lignina. O objetivo deste trabalho foi avaliar a eficiência da irradiação com feixe de elétrons como um pré-tratamento do bagaço-de-cana para o processo enzimático de hidrólise de celulose. As amostras de bagaço de cana-de-açúcar foram obtidas na Fazenda Iracema em Piracicaba, Brasil, com a colaboração do Centro de Tecnologia Canavieira e foram irradiadas usando Acelerador Industrial de Feixe de Elétrons de 1,5 MeV de energia e $25 \mathrm{~mA}$ da Radiation Dynamics Inc., USA., em sistema de batelada. O bagaço de cana da primeira amostragem, denominado Bagaço A, foi irradiado com doses absorvidas de 20 kGy, 50 kGy, 100 kGy, 150 kGy e 200 kGy e o da segunda amostragem, Bagaço B, foi irradiado com doses absorvidas de 5 kGy, 10 kGy, 20 kGy, 30 kGy, 50 kGy, 70 kGy, 100 kGy e 150 kGy. O processamento com feixe de elétrons levou a alterações na estrutura e na composição do bagaço de cana, foi responsável pela clivagem parcial da lignina, pela redução na celulose de alto peso molecular e também pelo aumento da celulose degradada. A radiação levou a um aumentou em cerca de $40 \%$ no rendimento da hidrólise enzimática da celulose para uma dose absorvida de 30 kGy. 


\title{
ELECTRON BEAM APPLICATION AS PRETREATMENT OF SUGARCANE BAGASSE TO ENZIMATIC HYDROLYSIS OF CELLULOSE
}

\section{Vanessa Miguel Cardoso}

\begin{abstract}
\end{abstract}
Due to increasing worldwide shortage of food and energy sources, sugarcane bagasse has been considered as a substrate for single cell protein, animal feed, and renewable energy production. Sugarcane bagasse generally contain up to $45 \%$ glucose polymer cellulose, much of which is in a crystalline structure, $40 \%$ hemicelluloses, an amorphous polymer usually composed of xilose, arabinose, galactose, glucose, and mannose and 20\% lignin, which cannot be easily separated into readily utilizable components due to their recalcitrant nature. Pure cellulose is readily depolymerised by radiation, but in biomass the cellulose is intimately bonded with lignin, that protect it from radiation effects. The objective of this study was the evaluation of the electron beam irradiation efficiency as a pre-treatment to enzymatic hydrolysis of cellulose in order to facilitate its fermentation and improves the production of ethanol biofuel. Samples of sugarcane bagasse were obtained in sugar/ethanol Mill sited in Piracicaba, Brazil, and were irradiated using Radiation Dynamics Electron Beam Accelerator with $1,5 \mathrm{MeV}$ energy and $37 \mathrm{~kW}$, in batch systems. The applied absorbed doses of the fist sampling, Bagasse A, were $20 \mathrm{kGy}, 50 \mathrm{kGy}, 100 \mathrm{kGy}$ and $200 \mathrm{kGy}$. After the evaluation the preliminary obtained results, it was applied lower absorbed doses in the second assay: $5 \mathrm{kGy}, 10 \mathrm{kGy}, 20 \mathrm{kGy}, 30 \mathrm{kGy}, 50 \mathrm{kGy}, 70 \mathrm{kGy}$, $100 \mathrm{kGy}$ and $150 \mathrm{kGy}$. The electron beam processing took to changes in the sugarcane bagasse structure and composition, lignin and cellulose cleavage. The yield of enzymatic hydrolyzes of cellulose increase about $40 \%$ with 30 kGy of absorbed dose. 


\section{SUMÁRIO}

1.0 INTRODUÇÃ

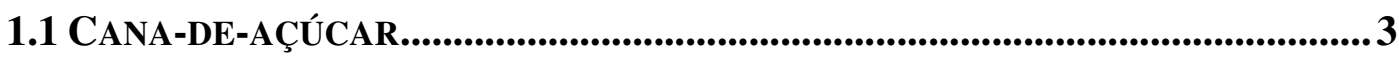

1.1.1 Bagaço da cana-de-açúcar ..................................................................

1.2 HIDRÓLISE DE CELULOSE DO BAGAÇO DA CANA-DE-AÇÚCAR ........................8

1.2.1 Processos de hidrólise quimica ………………….................................. 8

1.2.2 Processos de Hidrólise Enzimática ........................................................... 11

1.2.3 Pré-tratamento do bagaço da cana-de-açúcar para hidrólise enzimática

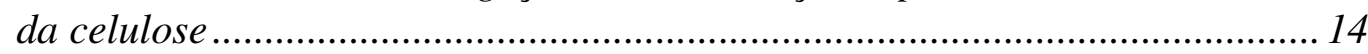

1.3 FUNDAMENTO DO PROCESSAMENTO POR RADIAÇÃO IONIZANTE................19

1.3.1 Fontes de radiação ionizante ................................................................ 21

1.4 EFEITO DA RADIAÇÃ̃O IONIZANTE NO BAGAÇO DA CANA-DE-AÇÚCAR .....24

1.5 FUNDAMENTOS TEÓRICOS DAS TÉCNICAS ANALÍTICAS ...............................27

1.5.1 Determinação de Lignina ........................................................................... 27

1.5.2 Determinação de Hemicelulose e Celulose ............................................... 28

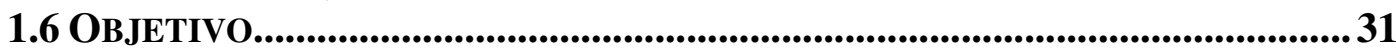

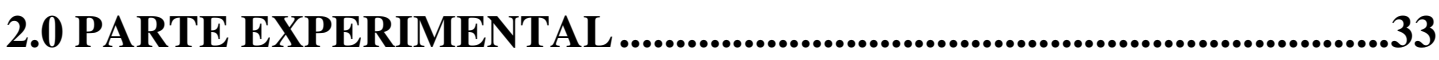

2.1 COLETA DE AMOSTRAS DE BAGAÇO DE CANA....................................................33

2.2 PROCESSAMENTO POR FEIXE DE ELÉTRONS ..................................................34

2.3 ENSAIOS PARA AVALIAÇÃO DOS EFEITOS DA RADIAÇÃO IONIZANTE ...........35

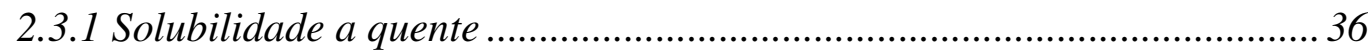

2.3.2 Solubilidade em Hidróxido de Sódio 1\%...................................................... 36

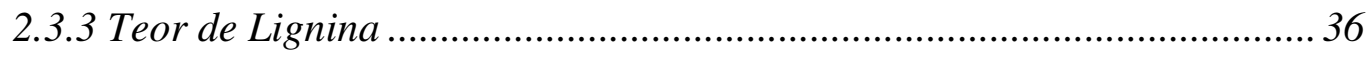

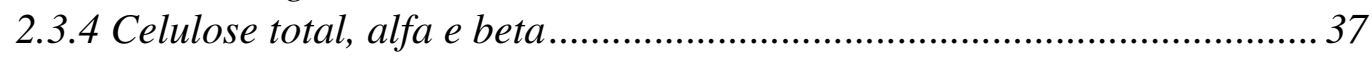

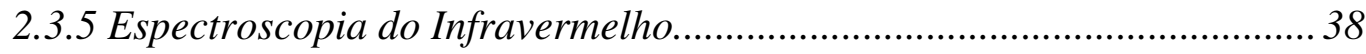

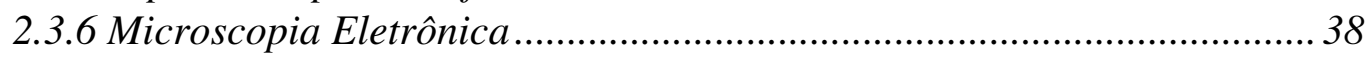

2.4 HIDRÓLISE ENZIMÁTICA.............................................................................39

3. RESULTADOS E DISCUSSÃO .........................................................40

3.1 EFEITOS DO PROCESSAMENTO POR FEIXE DE ELÉTRONS NAS

CARACTERÍSTICAS FÍSICO-QUÍMICAS DO BAGAÇO DE CANA ...............................40

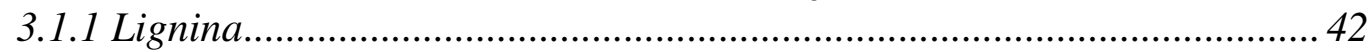

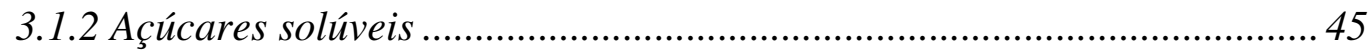

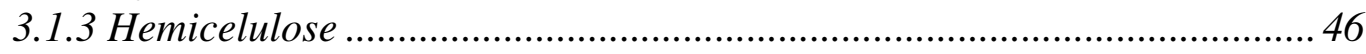

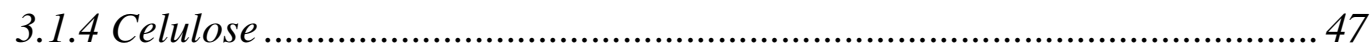

3.1.5 Espectroscopia do Infravermelho...........................................................53

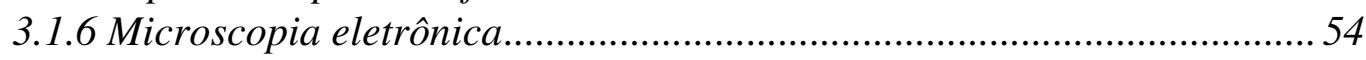

3.2 EFEITOS DO PROCESSAMENTO POR FEIXE DE ELÉTRONS NA HIDRÓLISE

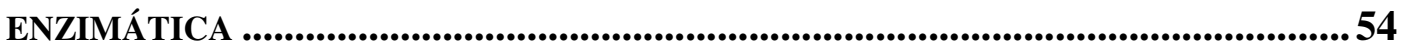

4.0. CONCLUSÕES.............................................................................................60

REFERÊNCIAS BIBLIOGRÁFICAS ...........................................................61 


\subsection{INTRODUÇÃO}

Numa crescente preocupação em reduzir as emissões de gases oriundos da queima de combustíveis fósseis ligados diretamente a mudança climática do nosso planeta, intensificou-se o interesse em substituir o combustível fóssil por combustíveis alternativos, sendo um deles o álcool, provido de fonte renovável e menos poluente. O Brasil produz atualmente cerca de 16 bilhões de litros de etanol combustível, o que representa 35\% do total mundial. Atualmente, um terço da biomassa contida na planta cana é aproveitado para a produção de açúcar e etanol (Ereno, 2007).

$\mathrm{O}$ aproveitamento do bagaço e da palha de cana-de-açúcar ainda merece muitos estudos. Eles são materiais constituídos por celulose, um polímero da glicose formado por seis carbonos, as hexoses; por hemicelulose, composta em sua maioria por açúcares de cinco carbonos, chamados de pentoses, não aproveitados ainda para a produção de açúcar e pela lignina formada por compostos fenólicos, um material estrutural da planta, associado à parede vegetal celular, responsável pela rigidez, impermeabilidade e resistência a ataques microbiológicos e mecânicos aos tecidos vegetais.

Diversas instituições brasileiras realizam pesquisas sobre o aproveitamento do bagaço-de-cana na produção de etanol. Essas investigações envolvem estudos da hidrólise de materiais lignocelulósicos, estudos sobre os pré-tratamentos envolvidos, sobre as enzimas hidrolíticas de celulose e sobre os processos de fermentação dos açúcares (Ereno, 2007; Copersucar, 2007; Petrobras, 2007).

A importância do desenvolvimento de processos de hidrólise, que sejam economicamente viáveis, está relacionada com a grande disponibilidade de material celulósico na maioria das regiões do mundo e no 
fato dos açúcares resultantes serem matéria-prima adequada, não só para produção de etanol, mas de uma grande variedade de outros químicos. Também se busca valorizar a lignina residual, através do desenvolvimento de seus derivados.

O processamento por radiação ionizante é uma potente tecnologia para acelerar o processo de hidrólise enzimática dos lignocelulósicos. O ataque com radicais hidroxila $(\mathrm{OH})$ é um caminho eficiente para a oxidação de compostos orgânicos em moléculas mais simples. A tecnologia nuclear tem sido usada na proteção e na conservação do meio ambiente. Seu emprego na destruição dos compostos orgânicos tóxicos presentes em amostras ambientais, água potável, solos e efluentes industriais tem sido objeto de estudo de vários autores no Brasil e no mundo (Duarte, 1999; Duarte et al. 2002, 2004, 2006; Mori et al., 2006).

Este trabalho é parte de um projeto intitulado "Studies of cellulose hydrolysis from sugarcane bagasse to production of ethanol bio-fuel and new polisacharides polymers applying ionizing radiation", financiado pela AIEA (Research Contract No. 14709), que está sendo desenvolvido em convênio com o Centro de Tecnologia Canavieira, CTC, situado em Piracicaba, SP, que atua há mais de 30 anos no desenvolvimento de tecnologias inovadoras para o setor canavieiro. Dessa forma o conhecimento de aplicação da tecnologia nuclear e a experiência de 15 anos de pesquisas com degradação de moléculas orgânicas em diversas matrizes do grupo de Centro de Tecnologia das Radiações do IPEN, serão enriquecidos pelo conhecimento da tecnologia envolvida no setor sucro-alcooleiro do CTC.

\subsection{Cana-de-açúcar}


O Brasil é um dos maiores produtores de cana-de-açúcar do mundo, apresentando uma área total de plantio da ordem de seis milhões de hectares, o que representa $10 \%$ da área cultivada. Dentre os subprodutos da indústria sucro-alcooleira, o bagaço é produzido na proporção de $280 \mathrm{~kg} / \mathrm{ton}$ de cana esmagada. $\mathrm{O}$ valor nutritivo desse subproduto é baixo, devido às ligações que ocorrem entre celulose, hemicelulose e lignina (Ereno, 2007).

Outro subproduto da cana é a palha (composta pelas pontas e folhas), que representa uma produção semelhante à do bagaço e hoje é, na sua grande maioria, queimada antes da colheita para viabilizar o corte manual da cana. Este processo de colheita com queimada será descontinuado no Estado de São Paulo até 2014, o que representará um grande aumento na disponibilidade de fibra (Ereno, 2007).

O álcool proveniente da cana-de-açúcar, além de emitir menor porcentagem de gases que contribuem para efeito estufa, 56\% menos se comparado à gasolina e 44,4\% se comparado ao etanol proveniente de milho, não requer as grandes quantidades de herbicidas e fertilizantes à base de nitrogênio como na cultura do milho. Além disso, trata-se de um combustível renovável e, portanto, toda poluição emitida por ele será reabsorvida pelas plantas cultivadas na safra seguinte (Bourne, 2007).

Os principais constituintes da cana-de-açúcar estão expostos na Tabela 1 (Copersucar, 2007).

Tabela 1. Principais constituintes da cana-de-açúcar 


\begin{tabular}{l|c}
\hline Açúcares & $\mathbf{7 5 - 9 3}$ \\
Sacarose & $70-91$ \\
Glicose & $2-4$ \\
Frutose & $2-4$ \\
Sais & $\mathbf{3 , 0 - 5 , 0}$ \\
De ácidos inorgânicos & $1,5-4,5$ \\
De ácidos orgânicos & $1,0-3,0$ \\
& \\
Proteínas & $0,5-0,6$ \\
Amidos & $0,001-0,05$ \\
Gomas & $0,3-0,6$ \\
Ceras e graxas & $0,05-0,15$ \\
Corantes & $3-5$ \\
\hline
\end{tabular}

Fonte- Copersucar, 2007.

\subsubsection{Bagaço da cana-de-açúcar}

As fibras do bagaço da cana-de-açúcar são recobertas de lignina, possuindo uma camada intermediária de hemicelulose e uma camada interna de celulose. O bagaço da cana-de-açúcar geralmente contém cerca de 50\% de celulose com estrutura cristalina, cerca de $30 \%$ de hemicelulose, e cerca de $20 \%$ de lignina. Um desenho esquemático da estrutura do bagaço de cana com seus componentes é apresentado na Figura 1 (Mosier, 2005). 


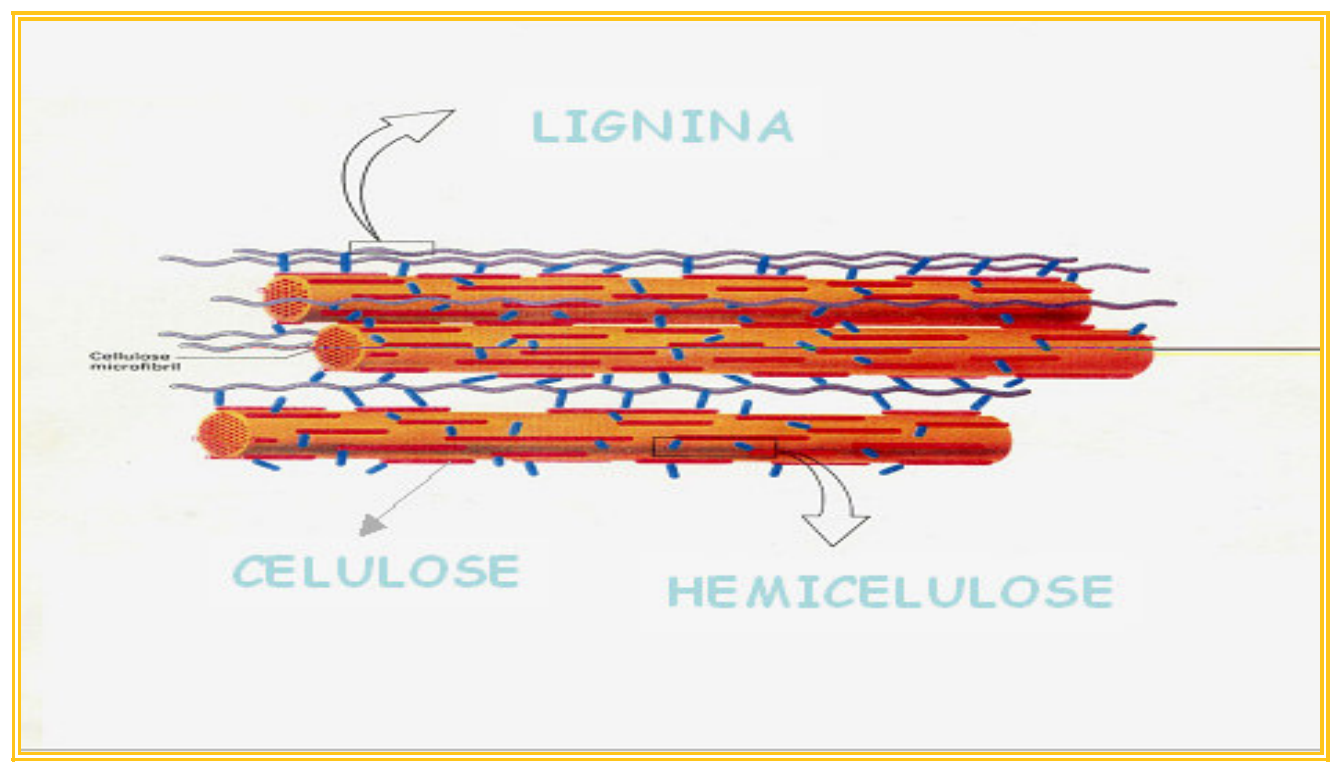

FIGURA 1. Desenho esquemático da composição da fibra do bagaço de cana (Mosier,2005)

\section{Lignina}

A lignina é um polímero fenólico, derivado de alcoóis aromáticos, que tem por função, conferir rigidez, impermeabilidade à água e resistência mecânica e microbiológica aos tecidos vegetais. É um heteropolímero tridimensional, reticular base fenólica, composta de três tipos de unidades de fenilpropano interligadas via sete tipos de ligações C-C ou C-O-C e grupos metoxila (Glasser and Kelly, 1987).

No processo de hidrólise convencional, para romper a camada de lignina, utiliza-se meio ácido com temperatura e pressão elevadas, mantendo estas condições por quatro a seis horas. Em virtude da lentidão do processo, os açúcares liberados acabam sendo degradados com a formação de substâncias tóxicas, o que prejudica o rendimento. A lignina é um subproduto do processo de hidrólise que poderá ser utilizado como fonte de energia térmica (Hassuani, 2005). 


\section{Celulose}

A celulose é um polímero natural de cadeia longa, de peso molecular variável e com fórmula empírica $\left(\mathrm{C}_{6} \mathrm{H}_{10} \mathrm{O}_{5}\right)_{\mathrm{n}}$, com um valor mínimo de $n=200$, composto de um só monômero que é um carboidrato, por isso classificada como polissacarídeo. É um componente estrutural primário das plantas e não é digerível pelo homem. Os animais ruminantes digerem a celulose com a ajuda de microorganismos simbióticos. Os resíduos de produtos agrícolas, chamados de biomassa, contêm quantidades significativas de celulose (Glasser and Kelly, 1987; Fengel and Wegener, 1989).

A estrutura da celulose forma-se pela união de moléculas de $\beta$ glucose, através de ligações $\beta-1-4$ glicosídicas, o que a torna insolúvel em água. Possui uma estrutura linear ou fibrosa, na qual se estabelecem múltiplas pontes de hidrogênio entre seus grupos hidroxilas, que correspondem a ligações, intramoleculares, entre moléculas de glicose e intermoleculares entre as distintas cadeias justapostas de glicose (Figura 2) (Glasser and Kelly, 1987; Fengel and Wegener, 1989).

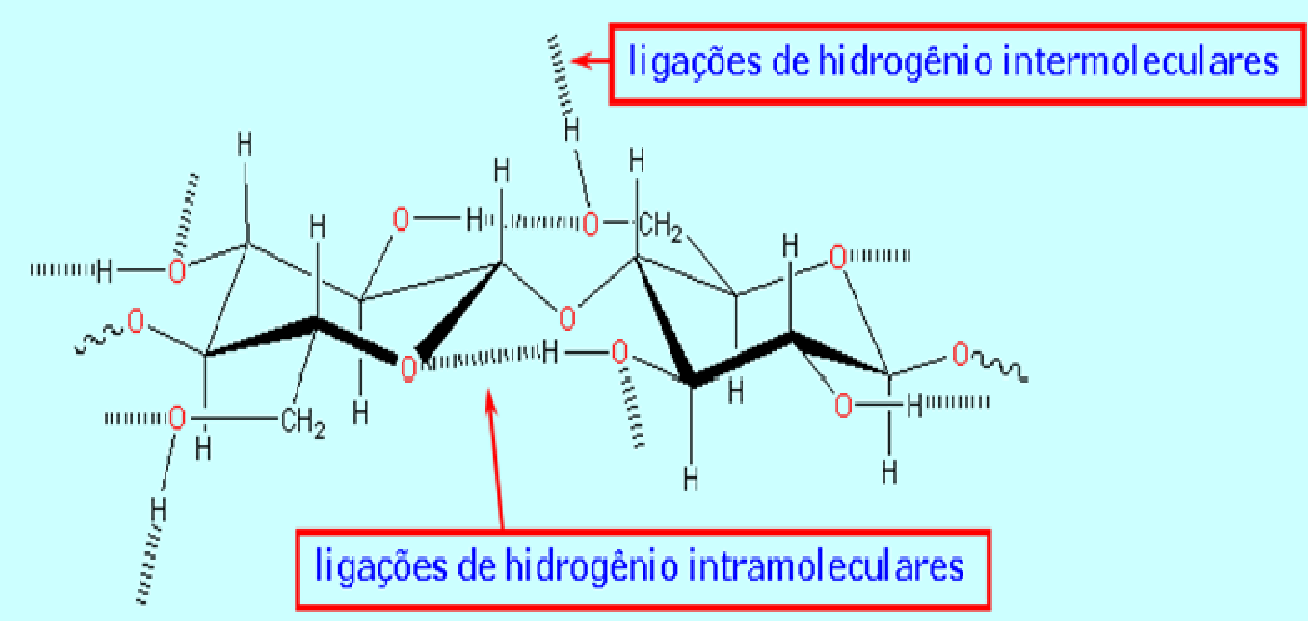

FIGURA 2. Estrutura da celulose (Glasser and Kelly, 1987) 
Industrialmente, a celulose é extraída da madeira de árvores como o pinho, o eucalipto ou o abeto ou de plantas herbáceas com grande quantidade de celulose no colmo, como a cana-de-açúcar, diversas gramíneas e os juncos. O algodão puro é formado em $99,8 \%$ de celulose. Conforme o tipo de árvore ou do tecido se obtém a celulose de fibra curta ou de fibra longa (Glasser and Kelly, 1987; Leonhardt et al, 1983).

\section{Hemicelulose}

A hemicelulose é um polímero amorfo composto de xilose, arabinose, galactose, glucose e manose. As diferenças principais entre celulose e hemicelulose são apresentadas na Tabela 2 (Fengel and Wegener, 1989).

Tabela 2. Diferenças principais entre celulose e hemicelulose

\begin{tabular}{|c|c|}
\hline CELULOSE & HEMICELULOSES \\
\hline $\begin{array}{l}\text { Consiste em unidades de } \\
\text { glicose ligadas entre si } \\
\text { (Natureza } \\
\text { Homopolissacarídica) }\end{array}$ & $\begin{array}{l}\text { Consistem em várias unidades de } \\
\text { pentoses e hexoses ligadas entre si } \\
\text { (Natureza Heteropolissacarídica) }\end{array}$ \\
\hline $\begin{array}{l}\text { Alto grau de polimerização } \\
(10.00 \text { a } 15.000)\end{array}$ & Baixo grau de polimerização (50 a 300) \\
\hline Forma arranjo fibroso & Não formam arranjo fibroso \\
\hline $\begin{array}{l}\text { Apresenta regiões cristalinas e } \\
\text { amorfas }\end{array}$ & Apresentam somente regiões amorfas \\
\hline $\begin{array}{l}\text { É atacada lentamente por } \\
\text { ácido inorgânico diluído a } \\
\text { quente }\end{array}$ & $\begin{array}{l}\text { São atacadas rapidamente por ácido } \\
\text { inorgânico diluído a quente }\end{array}$ \\
\hline É insolúvel em álcalis & São solúveis em álcalis \\
\hline
\end{tabular}

Fonte: Fengel and Wegener, 1989. 


\subsection{Hidrólise de celulose do bagaço da cana-de-açúcar}

Por várias décadas, a hidrólise eficiente de material lignocelulósico e a fermentação dos açúcares formados para produzir etanol, comercialmente, tem sido um grande desafio técnico por exigir temperatura e pressões elevadas ou sistemas enzimáticos complexos. Há dois processos comumente utilizados para obter-se o etanol a partir da celulose, em um deles a celulose é submetida ao processo de hidrólise enzimática, utilizando um complexo enzimático denominado celulase e o outro processo é chamado de químico e utilizam-se ácidos, temperatura e pressão elevadas (Brenner et al, 1979; Han et al., 1983; Kumakura and Kaetsu, 1978; Leonhardt et al., 1983).

A hidrólise de celulose produz hexoses (açúcares com moléculas de seis carbonos, como a glicose), que podem ser fermentadas com facilidade. Já a hemicelulose hidrolisada conduz à formação de pentoses (cinco carbonos, como a xilose). A fermentação de hexoses é muito fácil, mas para fermentar pentoses é necessário fermento específico, não disponível para aplicações industriais, atualmente. As pentoses podem ter no entanto, outras utilizações comerciais (Ereno, 2007).

Os processos em desenvolvimento para conversão da biomassa de natureza lignocelulósica em açúcares redutores e produção final de etanol, podem ser agrupados em três categorias principais, que são os processos que empregam ácidos concentrados, os processos catalisados por ácidos diluídos, e os processos enzimáticos (Ereno, 2007).

\subsubsection{Processos de hidrólise química}

Os processos por ácido concentrado empregam ácido sulfúrico como agente de pré-tratamento, seguido pelo estágio de hidrólise com ácido 
diluído. O ácido concentrado desfaz a estrutura cristalina da celulose. Assim que a estrutura da celulose passa ao estado amorfo, torna-se possível a sua transformação completa e rápida em açúcares redutores, empregando condições não muito severas de reação. O rendimento obtido é alto, porém o processo exige um investimento elevado em equipamentos. A recuperação do ácido sulfúrico exige consumo energético elevado. A operação em presença de um ácido forte provoca corrosão intensa e, conseqüentemente, problemas nos equipamentos, os quais requerem ligas especiais. A etapa de hidrólise gera subprodutos de reação indesejáveis, tais como: ácidos orgânicos de baixo peso molecular e compostos furânicos e fenólicos, que inibem a fermentação alcoólica (Hassuani, 2005).

Os processos que empregam ácidos diluídos, em geral, utilizam como catalisador o ácido sulfúrico diluído a $0,1-0,7 \%$ ou o ácido clorídrico. A hidrólise acontece em dois estágios para maximizar os rendimentos em açúcares redutores provenientes da hemicelulose e da celulose. O primeiro estágio é realizado em condições intermediárias para hidrolisar a hemicelulose, enquanto que o segundo, operando em condições mais severas, converte a celulose em açúcares redutores.

As pesquisas na área de produção de álcool de celulose por via ácida tiveram início em 1977, na Fundação de Tecnologia Industrial (FTI) Lorena, e as atividades abrangidas foram os estudos em laboratório, estudos em bancadas e escala-piloto. Os trabalhos foram continuados pela FAENQUIL, atualmente USP - Campus de Lorena, sendo este, o mais antigo grupo atuante no Brasil (Hassuani, 2005).

Outra pesquisa em hidrólise foi desenvolvida no Brasil em 1979, pela CODETEC - Companhia de Desenvolvimento Tecnológico, em conjunto com a companhia Aços Villares e com a Fundação Universidade Estadual de Campinas, quando realizaram pesquisas visando o desenvolvimento do 
processo de hidrólise ácida $\left(\mathrm{H}_{2} \mathrm{SO}_{4}\right)$ contínua do bagaço da cana-de-açúcar e de palha de arroz (Projeto HIDROCON).

Esses trabalhos foram descontinuados mesmo com o fato de os testes piloto apresentarem resultados promissores. Atingindo a escala piloto, com uma unidade tendo operado desde outubro de 1981 até o final de 1983 , foram atingidos rendimentos de sacarificação na faixa de 57\% a $60 \%$.

Várias plantas de hidrólise ácida foram instaladas durante a Segunda Guerra Mundial; processos catalisados por ácido diluído são ainda hoje usados na antiga União Soviética para produzir etanol e proteína unicelular, assim como o furfural. No entanto, as baixas taxas de conversão da celulose e da hemicelulose (50-60\% do teórico) tornam economicamente inviável o uso destas plantas. Os processos catalisados por ácidos concentrados têm uma taxa de conversão com valores adequados, mas nestes processos, o custo de recuperação dos ácidos é muito alto. Todos estes processos operam em batelada (Hassuani, 2005).

O processo Scholler-Madison Soviético, também foi implantado em escala industrial no Brasil à partir de 1980, através da COALBRA Coque e Álcool de Madeira S/A. Com a importação da tecnologia soviética, construiu uma fábrica com capacidade de produção de 30.000 1/dia de etanol. Esta planta, não chegou a atingir a sua plena capacidade operacional, devido a fatores econômicos desfavoráveis, tendo suas atividades encerradas em meados de 1987, quando se dedicava à produção de furfural.

A rota de hidrólise ácida também foi o caminho escolhido pelo grupo industrial Dedini, de Piracicaba, no projeto desenvolvido em parceria com o CTC e financiado pela FAPESP. Batizado de Dedini Hidrólise Rápida (DHR), o processo está em funcionamento, em fase de testes, em uma planta piloto de demonstração, com capacidade para 2 mil quilos por hora de bagaço, instalada na cidade de Pirassununga (SP). A Oxiteno, uma das 
maiores empresas brasileiras do setor químico, também está em busca de soluções tecnológicas para obtenção de etanol de celulose, mas não para uso como combustível. A empresa tem interesse em dominar o processo de hidrólise do bagaço e da palha para a fabricação de produtos químicos usados na indústria química e farmacêutica. São substâncias obtidas atualmente pela rota petroquímica, e a Oxiteno é um dos principais fabricantes desses produtos (Ereno, 2007; Processo, 2007).

\subsubsection{Processos de hidrólise enzimática}

Os processos enzimáticos empregam celulase como biocatalisador de hidrólise, que requer condições brandas, temperaturas próximas a $50^{\circ} \mathrm{C}$, pH na faixa 4,5-6,0 e operação nas pressões atmosféricas, permitindo ainda, conversões superiores às obtidas pela hidrólise química, menor destruição de açúcares e menor acúmulo de inibidores de fermentação. As principais barreiras aos processos enzimáticos são: o custo muito elevado da enzima celulase e o tempo mais longo para se obter rendimentos altos; um consumo energético elevado para manter os grandes volumes agitados e aquecidos por 48 a 96 horas, também torna-se uma barreira (Ereno, 2007; Hassuani, 2005; Glasser and Kelly, 1987; Fengel and Wegener, 1989).

Os processos catalisados por enzimas são objeto da maior parte dos estudos efetuados atualmente em nível mundial; em princípio, por oferecerem maior conversão e um grande potencial de redução de custos a médio/longo prazo. Há várias opções de processos em estudo hoje, mas nenhum em fase comercial.

\section{Celulases}

A celulase refere-se a uma classe de enzimas que são produzidas essencialmente por fungos, bactérias e protozoários e catalisam a hidrólise 
da celulose. As celulases surgiram como subprodutos da Segunda Guerra Mundial. Preocupados com o excessivo desgaste de roupas e equipamentos nas selvas do Pacífico Sul, em 1944, militares norte-americanos recolheram amostras de microrganismos suspeitos de serem os responsáveis pelo prejuízo e as levaram ao laboratório de pesquisas do exército, em Natick, Massachussetts. De milhares de amostras, uma, recolhida na Nova Guiné, mostrou conter um fungo - Trichoderma viride (atualmente denominado $T$. reesei, em homenagem ao seu descobridor, Elwyn Reese) - capaz de converter celulose em seus monômeros (Ereno, 2007; Hassuani, 2005; Fengel and Wegener, 1989).

O fungo só voltou a despertar interesse na década de 60 , quando se descobriu que preparados de enzimas extracelulares eram responsáveis pela ação hidrolítica. A idéia de aproveitar essas enzimas na conversão de resíduos celulósicos em produtos de interesse alimentar e energético surgiu em 1973, e em 1979, a equipe de Natick anunciava o isolamento de cepas mutantes de T.reesei com poder hidrolítico vinte vezes superior ao da cepa nativa.

O microrganismo original continua sendo o ponto de partida para as celulases comerciais do século XXI. A técnica para o desenvolvimento de cepas com maior rendimento em celulases extracelulares compreende a indução de mutações, geralmente com radiação ultravioleta ou pelo emprego de substâncias mutagênicas, como nitrosoguanidina, NTG.

As celulases são relativamente pouco conhecidas em comparação com outras enzimas e admite-se a existência de cinco tipos, das quais ao menos três formam um complexo sinérgico, responsável pela hidrólise da celulose (Figura 3) (Fengel and Wegener, 1989):

- A endocelulase, Endo beta 1,4 glucanase (EGI, EGII, EGIII, EGIV e EGV) responsável pelo rompimento de ligações 
intercadeias poliméricas, que conferem estrutura cristalina à celulose, hidrolisam ligações glicosídicas ao acaso;

- A exocelulase, Exo beta 1,4 glucanase (EGI e EGII) cliva segmentos das cadeias expostas pela endocelulase, nas extremidades redutoras e não redutoras do polímero, gerando oligossacarídeos como a celobiose (dissacarídeo) ou a celotetrose (tetrassacarídeo) e

- A beta-glucosidase, Beta 1,4 glucosidase (EGI e EGII) hidrolisa celobiose e celodextrinas, gerando monômeros de glicose.

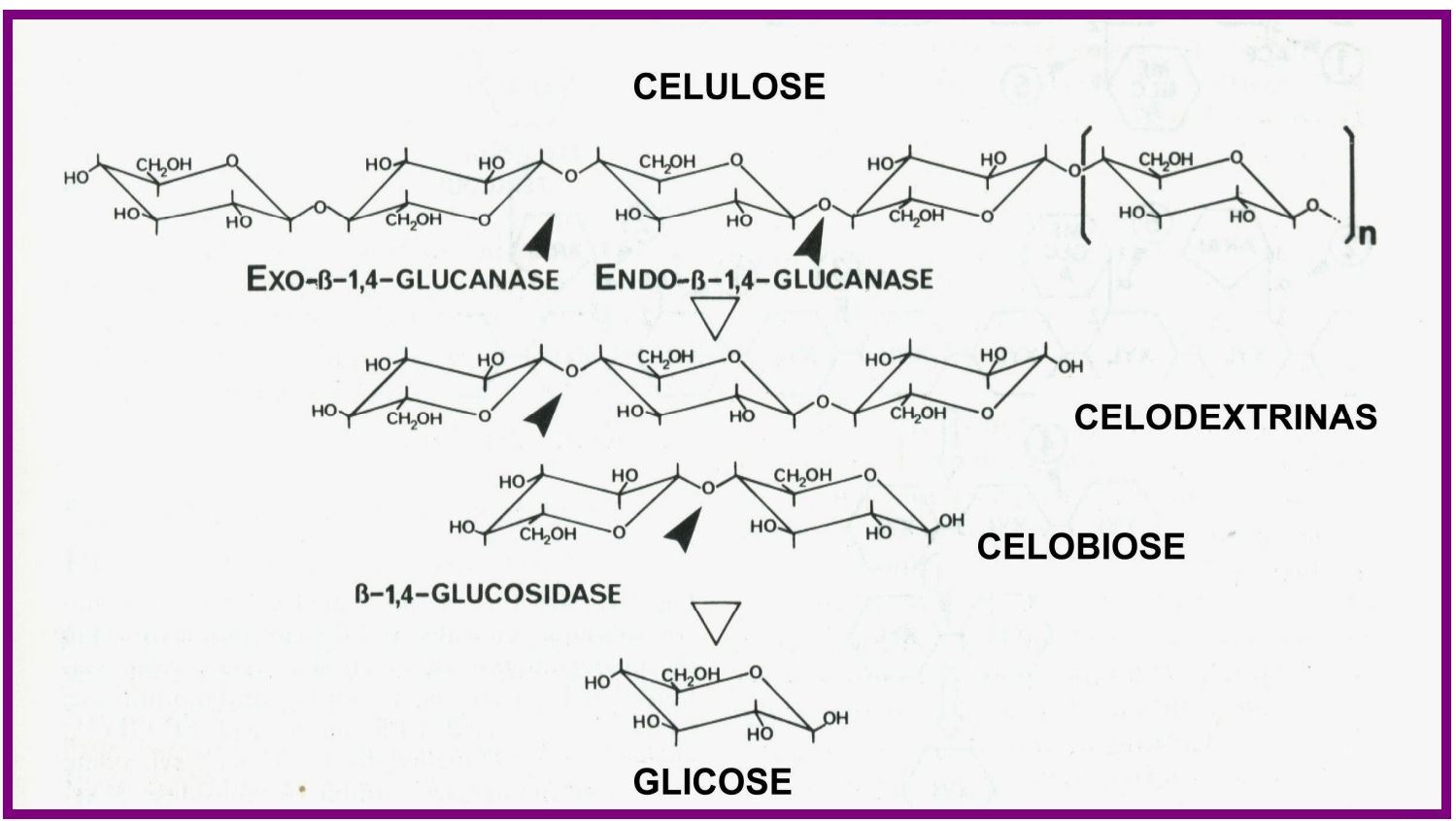

FIGURA 3. Ação do complexo celulase na hidrólise da celulose e compostos intermediários (Fengel and Wegener, 1989)

A evolução tecnológica da rota celulolítica ainda não ultrapassou estágios pré-industriais porque a celulase encarece o processo, tirando-lhe competitividade. Em 2001, cada litro de álcool produzido por hidrólise enzimática custava aproximadamente US\$ 1,30 em celulase. Três anos 
depois, a enzima teve seu preço reduzido em dez vezes, mas ainda assim não é competitivo.

Empresas de alta tecnologia, como Novozymes e Genencor, ambas, coincidentemente, controladas por grupos industriais dinamarqueses, trabalham no sentido de remover este último obstáculo ao aproveitamento energético da celulose. A Genencor acaba de lançar a "Accellerase 1000", fruto de dez anos de pesquisa e desenvolvimento, $\mathrm{P} \& \mathrm{D}$, na criação de enzima especificamente desenvolvida para usinas de álcool. Assim, apresenta alta atividade de beta-glicosidase, o que evita o acúmulo de celobiose, prejudicial ao rendimento da sacarificação.

A Novozymes, por sua vez, anunciou ter concluído em 2005 programas conjunto de P\&D com o National Renewable Energy Laboratory (NREL) (Golden, Colorado, subordinado ao Departamento de Energia dos EUA), que, ao longo de quatro anos e ao custo de US\$ 17,1 milhões, viabilizou o desenvolvimento de uma enzima que poderá custar apenas US\$ 0,03 a 0,05 por litro de álcool produzido. Para especialistas, o valor já está próximo daquele considerado ideal (US\$ 0,01/litro), fazendo com que prevejam a esperada proliferação de usinas celulolíticas a partir da virada da década.

\subsubsection{Pré-tratamento do bagaço da cana-de-açúcar para hidrólise enzimática da celulose}

Para que as biomassas possam ser utilizadas como matérias-primas para processos químicos e biológicos elas precisam ser submetidas a um prétratamento para desorganizar o complexo lignocelulósico. A lignina é o grande obstáculo nesse processo todo. A quebra desse componente libera fenóis e outros produtos químicos que inibem o processo fermentativo. Só 
após ser feito o pré-tratamento do material aplica-se uma das duas vias de transformação da celulose em açúcar para obtenção do etanol.

As celulases, por serem proteínas, não conseguem penetrar com facilidade a barreira da lignina das células vegetais e, dessa forma, o difícil acesso destas enzimas às fibras de celulose constitui o principal problema para desencadeamento desse processo de degradação (Martin et al., 2002).

A etapa de fermentação alcoólica da fração de hexoses no licor de hidrólise é feita por uma linhagem selecionada de levedura conhecida como Sacharomyces cerevisiae, sendo que, o maior problema encontrado, é a inibição do metabolismo da levedura pelos subprodutos gerados durante o pré-tratamento e a hidrólise. O vinho final da fermentação, contendo o etanol, passa por estágios de destilação e retificação, para se obter o Etanol Hidratado Carburante (AEHC). Passa ainda, por um estágio adicional de destilação azeotrópica ou extrativa/absorção, para obter o Etanol Anidro Carburante (AEAC) (Martin et al, 2002).

Vários tipos de pré-tratamentos podem ser aplicados com o objetivo de diminuir o teor de lignina e facilitar a posterior hidrólise enzimática por celulases. Por outro lado, nas fibras de celulose coexistem regiões de alta cristalinidade e regiões amorfas menos organizadas. Quanto maior for a proporção da forma cristalina, maior a resistência ao ataque enzimático. Deste modo, os sistemas de pré-tratamento, além de permitir a deslignificação do material, podem diminuir a cristalinidade da celulose, podendo ser fundamentais para o decorrer do ataque enzimático subseqüente, como esquematizado na Figura 4.

Todas as tecnologias de hidrólise requerem um tratamento físico preliminar de eliminação de impurezas e preparo do material lignocelulósico por redução do tamanho das partículas a tratar. Esta redução de tamanho, traz como vantagem o aumento da superfície específica do material, acelerando 
assim, a reação de hidrólise. Uma das vantagens do bagaço comparado com outros materiais lignocelulósicos, é a de já estar semi-preparado e ter baixo teor de umidade. É uma tendência geral nos processos a introdução de um pré-tratamento físico-químico ou químico, para facilitar a hidrólise propriamente dita e atingir altas taxas de sacarificação, baixa formação de subprodutos indesejáveis e elevado coeficiente de conversão dos celulósicos em carboidratos monoméricos (Mosier et al., 2005).

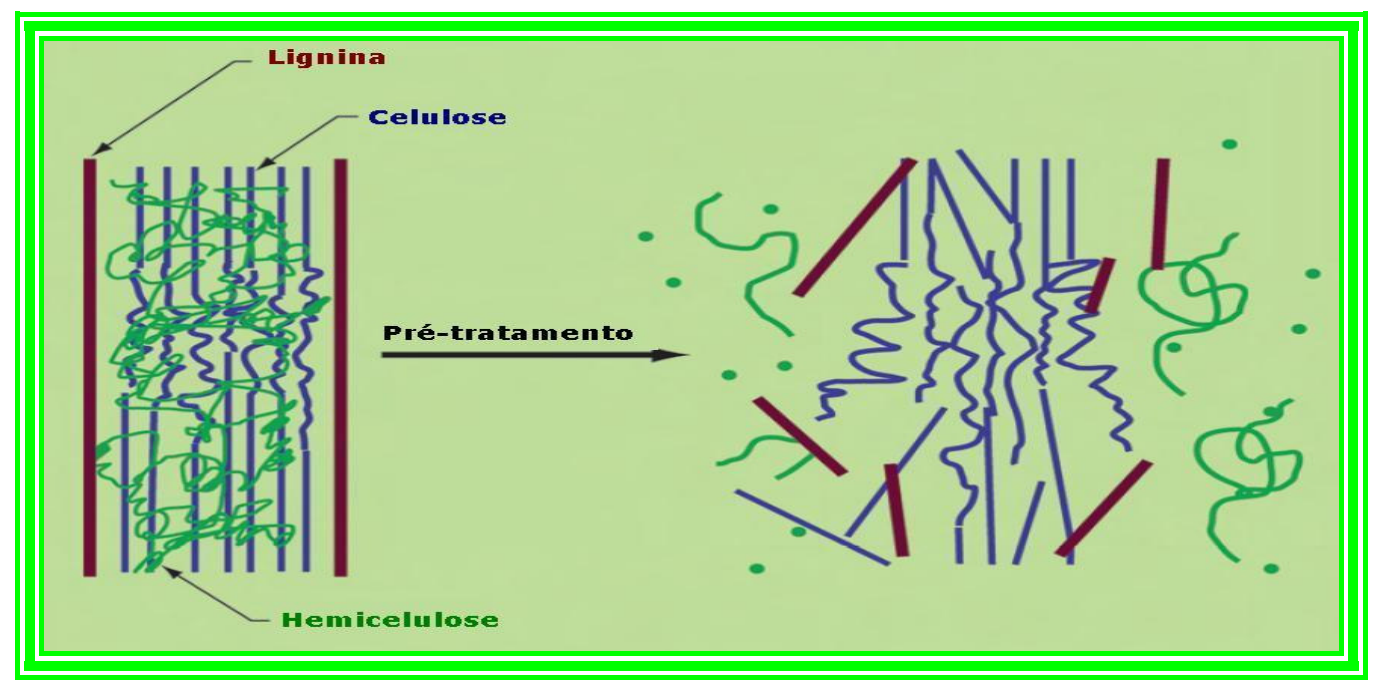

FIGURA 4. Desenho esquemático do efeito do pré-tratamento para hidrólise da celulose (Mosier et al, 2005)

Os processos de pré-tratamento mais comuns são o craqueamento a vapor, o Organosolv e o aquecimento da biomassa em presença de ácido diluído.

\section{Craqueamento com vapor (steam explosion)}

A biomassa é submetida a uma exposição a vapor vivo, até atingir uma temperatura elevada $\left(180-240^{\circ} \mathrm{C}\right)$, por tempos de permanência curtos $(10$ 
segundos a 5-10 minutos) e, a seguir, efetua-se uma descompressão instantânea. O produto final apresenta: hidrólise parcial da hemicelulose, fusão da lignina e diminuição do grau de polimerização da celulose. A eficiência do processo de craqueamento com vapor, pode ser melhorado quando o material recebe uma impregnação prévia com ácido sulfúrico diluído. Esse pré-tratamento é feito há tempos na produção de ração animal (Mosier et al,2005).

\section{Processo Organosolv}

Este processo, originário da indústria da celulose, emprega solventes orgânicos recuperáveis, capazes de remover a lignina, deslignificando a madeira. Como vantagem, esse processo permite reduzir o emprego de reagentes químicos agressivos, tais como a soda cáustica, o sulfito e outros.

A primeira adaptação desta tecnologia, como auxílio na hidrólise, surgiu no Canadá empregando-se acetona como solvente. Mais recentemente, processos empregando metanol e etanol estão sendo levados à prática. Os processos se baseiam no cozimento da biomassa lignocelulósica com o solvente Organosolv, à elevada temperatura e pressão e posterior recuperação da celulose e da lignina. $O$ solvente orgânico é removido e recuperado por evaporação e destilação, sendo reciclado no processo (Ereno, 2007).

Os aspectos a serem resolvidos são:

- Evitar decomposição ou reação química do solvente orgânico;

- Desenvolver método de recuperação da fase orgânica e dos subprodutos com baixo consumo energético e pequenas perdas do solvente; 
- Evitar perdas físicas do solvente, principalmente nos solventes de volatilidade alta, ou perdas por arraste com o licor hidrolítico final.

Considerando que o tratamento é eficiente para a remoção da lignina, gerando uma celulose muito susceptível ao ataque posterior, o desenvolvimento deste processo deve ser direcionado para a procura de novos solventes, que permitam aperfeiçoar as condições de pré-tratamento, reduzindo as perdas e o consumo energético.

Um projeto utilizando solvente orgânico, para extração da lignina, e ácido diluído, é desenvolvido pelo grupo Dedini desde 1980. As pesquisas iniciadas pela Dedini em laboratório, contaram com a parceria da Rhodia e se estenderam até 1996. À partir desta data, o desenvolvimento do processo teve continuidade pela Dedini e o CTC - Centro de Tecnologia Canavieira, contando com o apoio da FAPESP (Ereno, 2007).

Originalmente o processo foi desenvolvido para um solvente orgânico baseado na mistura de acetona/água e depois, à partir de 1999, para etanol/água. O processo originado em patentes de Lazlo Panzer, foi totalmente reformulado para as condições brasileiras e adaptado ao setor sucro-alcooleiro, tornando-se um novo conceito de tecnologia Organosolv patenteado pela Dedini, com o nome de Dedini Hidrólise Rápida- DHR. O DHR passou por estágios de desenvolvimento em laboratório, em escala piloto, até atingir o estágio atual de uma planta semi-industrial, denominada de Unidade de Desenvolvimento de Processo - UDP, com capacidade equivalente a 5000 litros de etanol por dia (Processo DHR, 2007). 


\section{Aquecimento da biomassa em presença de ácido diluído}

Nesse processo utiliza-se ácido diluído numa relação de 1 a $3 \%$ da biomassa seca e a temperaturas de até $200{ }^{\circ} \mathrm{C}$ por curto tempo, da ordem de segundos. Nestes processos, a conversão da hemicelulose é eficiente e conduz a uma alta recuperação dos carboidratos monômeros. A biomassa tratada por estes procedimentos apresenta uma melhor digestibilidade ácida ou enzimática. As desvantagens destes tratamentos estão associadas à necessidade de requerer um pós-tratamento de neutralização da acidez com calcário, gerando como resíduo o gesso. A recuperação do gesso gerado pelos processos, utilizando ácido sulfúrico, é complexa e o seu descarte representa um problema ambiental sem solução adequada até hoje.

\subsection{Fundamento do processamento por radiação ionizante}

A utilização de Processos de Oxidação Avançada, POAS, como o pré-tratamento com ozônio, UV e $\mathrm{H}_{2} \mathrm{O}_{2}$ são bastante freqüentes na indústria de papel e celulose, principalmente em função do poder branqueador e da sua natureza não-poluente. A ação da radiação ionizante engloba os efeitos desses três processos simultaneamente, pois é mais penetrante que radiação UV e na radiólise da água, além do radical hidroxila que é altamente oxidante, forma $\mathrm{H}_{2} \mathrm{O}_{2}$ pela recombinação de radicais e íons superóxidos pela reação do $\mathrm{OH}^{*}$ com o oxigênio dissolvido.

A radiólise dos compostos orgânicos pode se dar pela interação direta da radiação ionizante na molécula ou pela interação indireta com os produtos da radiólise da água. A ação direta da radiação é insignificante mesmo em casos de concentrações altas dos compostos. Na radiólise indireta

a molécula do composto reage com os radicais $\mathrm{e}_{\mathrm{aq}}^{-}, \mathrm{H}, \mathrm{OH}^{\cdot}$ e o produto 
molecular $\mathrm{H}_{2} \mathrm{O}_{2}$ que são formados na seguinte proporção (Getoff, 1986; Wood, 1998):

$$
\mathrm{H}_{2} \mathrm{O} \rightarrow[2.6] \mathrm{e}^{-}{ }_{\text {qq }}+[0.6] \mathrm{H}^{\cdot}+[2.7] \cdot \mathrm{OH}+[0.7] \mathrm{H}_{2} \mathrm{O}_{2}+[2.6] \mathrm{H}_{3} \mathrm{O}^{+}+[0.45] \mathrm{H}_{2}
$$

Dos produtos formados, as espécies mais reativas são o radical hidroxila oxidante $\left(\mathrm{OH}^{*}\right)$, o elétron aquoso redutor $\left(\mathrm{e}_{\mathrm{aq}}^{-}\right)$e o átomo de hidrogênio $\left(\mathrm{H}^{\prime}\right)$. Assim, os processos químicos básicos vão se dar pela reação com estas três espécies.

\section{Elétron aquoso}

A reação do elétron aquoso com compostos orgânicos e inorgânicos específicos tem sido estudada extensivamente; é um potente redutor e atua na transferência de um elétron, sendo importante sua reação com compostos halogenados. Uma reação generalizada é mostrada abaixo:

$$
\mathrm{e}_{\mathrm{aq}}^{-}+\mathrm{RCl} \rightarrow \mathrm{R}^{\cdot}+\mathrm{Cl}^{\cdot}
$$

\section{Átomo de hidrogênio}

O processo de feixe de elétrons é o único que forma este radical. O $H^{*}$ reage com os compostos orgânicos por dois processos gerais, a adição e a subtração de hidrogênio. Um exemplo de adição é a reação com a molécula de benzeno:

$\mathrm{H}^{\cdot}+\mathrm{C}_{6} \mathrm{H}_{6} \rightarrow \mathrm{C}_{6} \mathrm{H}_{7} \cdot$

A segunda reação geral envolvendo o $\mathrm{H}^{\cdot}$ é a abstração:

$\mathrm{H}^{\cdot}+\mathrm{CH}_{3} \mathrm{OH} \rightarrow \mathrm{H}_{2}+{ }^{\cdot} \mathrm{CH}_{2} \mathrm{OH}$ 


\section{Radical hidroxila}

$\mathrm{O} \cdot \mathrm{OH}$ pode reagir de várias formas com químicos em solução aquosa, os tipos mais comuns de reação são: adição, abstração de hidrogênio, transferência de elétrons e recombinação radical-radical. Reações de adição ocorrem prontamente com compostos aromáticos e alifáticos insaturados:

\section{$\cdot \mathrm{OH}+\mathrm{CH}_{2}=\mathrm{CH}_{2} \rightarrow \mathrm{HOCH}_{2}-\mathrm{CH}_{2} \cdot$}

Reações de abstração ocorrem com moléculas saturadas e insaturadas, como aldeídos e cetonas:

$$
\cdot \mathrm{OH}+\mathrm{CH}_{3}-\mathrm{CO}-\mathrm{CH}_{3} \rightarrow \mathrm{CH}_{2} \mathrm{COCH}_{3}+\mathrm{H}_{2} \mathrm{O}
$$

Reações de transferência de elétrons são também comuns e ocorrem quando soluções aquosas são irradiadas com elétrons de alta energia. Por exemplo, reações envolvendo íons halogênios (X-) podem ocorrer:

$\mathrm{OH}+\mathrm{X}^{\cdot} \rightarrow \mathrm{X}^{\cdot}+\mathrm{OH}^{-}$

$\mathrm{X}^{\cdot}+\mathrm{X}^{-} \rightarrow \mathrm{X}_{2}^{-\cdot}$

$\mathrm{O} \mathrm{X}_{2}{ }^{-\cdots}$ Pode reagir com moléculas orgânicas formando compostos orgânicos halogenados. Os halogênios de maior interesse são o $\mathrm{Cl}^{-}$e $\mathrm{Br}^{-}$.

\section{Peróxido de hidrogênio}

A principal reação resultante na formação de $\mathrm{H}_{2} \mathrm{O}_{2}$ é a recombinação radical-radical envolvendo $\mathrm{OH}$ :

$\cdot \mathrm{OH}+\cdot \mathrm{OH} \rightarrow \mathrm{H}_{2} \mathrm{O}_{2}$

Pode ocorrer também a dissociação do peróxido de hidrogênio:

$\mathrm{e}_{\mathrm{aq}}^{-}+\mathrm{H}_{2} \mathrm{O}_{2} \rightarrow \cdot \mathrm{OH}+\mathrm{OH}^{\cdot}$

\subsubsection{Fontes de radiação ionizante}

No Processo de Oxidação Avançada por radiação ionizante empregam-se, basicamente, dois tipos de irradiadores: aqueles que utilizam 
radioisótopos artificiais emissores gama como Cobalto-60 e Césio-137 e os aceleradores de elétrons.

As fontes gama requerem blindagens especiais de concreto com paredes espessas e são usadas principalmente na esterilização de produtos médicos e irradiação de alimentos, onde a penetração maior da radiação é uma vantagem. Os aceleradores de elétrons são geralmente preferidos como fonte de radiação para aplicações ambientais e industriais.

As vantagens do acelerador de elétrons são: taxa de dose alta, rendimento maior de energia, licenciamento similar às máquinas de Raios-X e o sistema liga-desliga que cessa a emissão da radiação ionizante. As desvantagens são: a penetração baixa dos elétrons e a necessidade de operadores especializados (Pikaev, 1995; American, 1992).

Um acelerador de partículas pode ser definido como um equipamento que transfere energia a partículas carregadas por um processo físico que emprega uma combinação de campos elétricos e magnéticos, gerando íons de alta energia cinética. Por outro lado quando se estabelece um potencial de alta voltagem entre catodo e anodo no vácuo, no cátodo por efeito termelétrico, ocorre a emissão de raios catódicos que são feixe de elétrons. Estas partículas são aceleradas, seguindo o mesmo princípio do tubo de televisão; a diferença fundamental é que este último utiliza cerca de 25.000 volts de energia enquanto que o acelerador utiliza da ordem de milhões de volts (Figura 5) (Bly, 1988; Radiation, s.d.). 


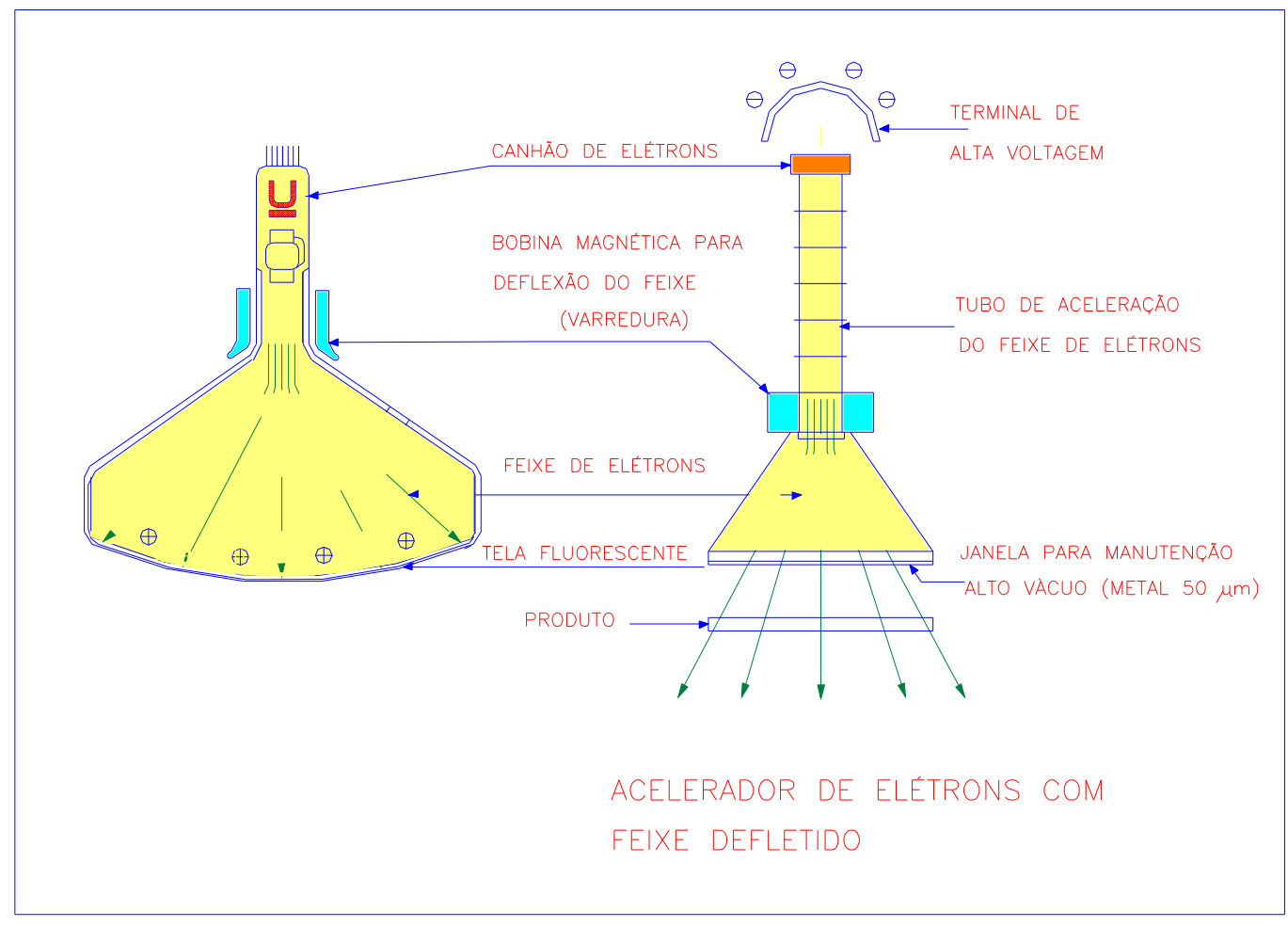

Figura 5 - Comparação entre acelerador de elétrons e o tubo de televisão (Radiation, s.d.)

Os aceleradores lineares industriais possuem um sistema de varredura onde se processa a deflexão oscilante do feixe de elétrons, deflexão esta provocada por um campo eletromagnético que oscila em torno de 100 ciclos por segundo. O sistema de varredura logo após o tubo de aceleração opera em condições de alto vácuo. Sua extremidade está fechada hermeticamente por uma janela fina, de alta resistência mecânica e térmica, que produz um mínimo de atenuação na intensidade do feixe incidente, geralmente, esta janela é de titânio (Bly, 1988).

O campo de aplicação dos aceleradores está delimitado tecnicamente por dois parâmetros: voltagem de aceleração dos elétrons e corrente na saída. A voltagem determina a energia cinética dos elétrons e, portanto, a penetração dos elétrons no material irradiado. $\mathrm{O}$ alcance máximo dos elétrons é diretamente proporcional à sua energia e inversamente proporcional à 
densidade do absorvente. A corrente de saída é proporcional à quantidade de elétrons que incide no material a ser irradiado e está diretamente relacionada com a dose. $\mathrm{O}$ produto da voltagem de aceleração pela corrente do feixe eletrônico define a potência do acelerador (Bly, 1988).

Aceleradores de energia intermediária de $0,5 \mathrm{MeV}$ a 5,0 MeV e potência do feixe de $300 \mathrm{~kW}$ a $350 \mathrm{~kW}$ são utilizados em muitas áreas de processamento por radiação como reticulação de polímeros, vulcanização de elastômeros e cura de tintas e vernizes. Aceleradores de alta energia, de $5 \mathrm{MeV}$ a $10 \mathrm{MeV}$ e potência do feixe acima de $100 \mathrm{~kW}$, são usados na esterilização de produtos médicos-cirúrgicos e no processamento de alimentos (Pikaev, 1995).

O acelerador de elétrons é uma alternativa em aplicações ambientais, porque funciona a base de eletricidade e, de acordo com a finalidade, máquinas de pequeno porte podem ser construídas, facilitando o manuseio e o transporte para uso em diferentes locais podendo ser usado em associação com outras técnicas. A distribuição não homogênea da dose na camada irradiada tem sido resolvida com o desenvolvimento de sistemas de irradiação adequados (Pikaev, 1995; Waite, 1992; Duarte, 1999).

\subsection{Efeito da radiação ionizante no bagaço da cana-de-açúcar}

$\mathrm{Na}$ literatura encontram-se vários estudos de irradiação de fibras celulósicas ou do bagaço da cana-de-açúcar com objetivos distintos, ou para melhorar a digestibilidade e ser usada como ração animal, ou para melhorar as características do produto final, no caso da indústria têxtil. $O$ efeito da radiação ionizante em celulose purificada, tal como de algodão e de madeira, tem sido extensivamente estudado (Dubey et al., 2004; Foldvary et al., 2003; 
Gabrielli et al., 2000; Khan et al., 2006; Takács et al., 2000). Muitos estudos têm sido feitos também com o objetivo de hidrolisar a celulose para obter açúcares e outros compostos químicos (Brenner et al., 1979; Takács et al., 2000; Vitti et al., 1998).

O processo por radiação ionizante é uma potente tecnologia para acelerar a reação de hidrólise de celulose, podendo provocar à quebra da cadeia formada por moléculas de celulose. Na Figura 6 é apresentado um esquema do local de decomposição preliminar da celulose (Khan et al., 2006).

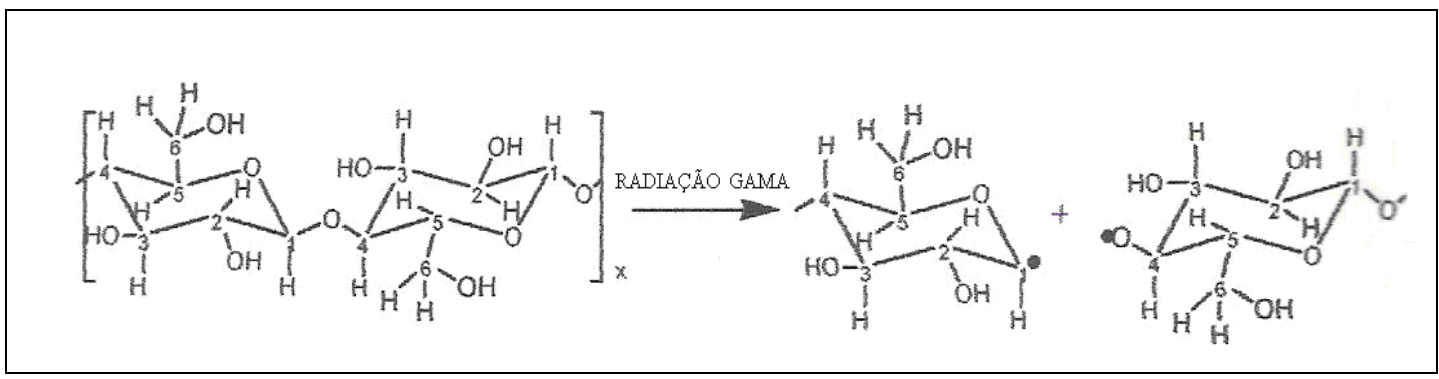

Figura 6. Quebra da cadeia da unidade da celulose (Khan et al., 2006)

A celulose pura é prontamente despolimerizada pela radiação ionizante, mas quando ela está ligada com lignina, no caso de madeiras naturais, o processo é mais difícil. A lignina protege a celulose dos efeitos da radiação. Quando comparada com outros polímeros naturais, a celulose mostra uma anormal suscetibilidade à degradação por radiação (Ereno, 2007; Takács et al., 2000).

Em um estudo realizado por Vitti et al. (1998), amostras de bagaço da cana-de-açúcar e resíduos de cultura de arroz e algodão foram irradiadas com feixes de elétrons, para verificar os efeitos da irradiação na digestibilidade da matéria seca e na sua composição química e estrutural. Os tratamentos consistiram na aplicação de 200 kGy, 400 kGy, 600 kGy, 800 kGy e 1000 kGy com ou sem aplicação de amônia gasosa para o bagaço da cana-de-açúcar e 200 kGy com e sem amônia para os resíduos de cultura de 
arroz e algodão. A irradiação produziu uma redução nos conteúdos de fibra bruta e fibra detergente neutro. O teor de compostos fenólicos aumentou com a dose aplicada, sugerindo quebras na estrutura do complexo lignocelulósico. Verificou-se também, um aumento na digestibilidade com o aumento da dose absorvida. Para o bagaço da cana-de-açúcar, as doses mais elevadas produziram um aumento de 24 vezes em digestibilidade em relação ao material não tratado; para os restos de cultura os aumentos foram menores. Concluiu-se que a irradiação com feixe de elétrons levou a alterações significativas na composição química, estrutural e na digestibilidade de resíduos fibrosos.

$\mathrm{Na}$ irradiação com feixe de elétrons os produtos da radiólise da água tendem a reagir com os grupos funcionais presentes nas moléculas orgânicas preferencialmente à molécula como um todo. Alguns grupos funcionais como os tióis e aqueles contendo múltiplas insaturações, são atacados preferencialmente se estiverem presentes (Getoff, 2006).

A ação da radiação ionizante em macromoléculas de materiais lignicelulósicos se dá pela interação dos radicais livres produzidos tanto pela ação da interação da água presente como umidade no bagaço da cana-deaçúcar, como pela ação direta nas ligações de átomos de carbono e oxigênio. A radiação ionizante no material lignocelulósico pode levar à ruptura das ligações ou à polimerização (cross-linking). A eficiência desses dois processos vai depender da estrutura do polímero e da dose absorvida (Han et al., 1983; Liu et al., 2006, Lepifre et al., 2004).

Estudos na literatura têm mostrado que a radiação ionizante, leva à diminuição no grau de polimerização e aumenta o conteúdo de carbonilas na celulose. Outros estudos mostram que, como um método de pré-tratamento, a radiação ionizante é equivalente, em termos de digestibilidade, ao tratamento 
com $\mathrm{NaOH}$, um dos métodos mais utilizados para aumentar a digestibilidade (Khan et al., 2006; Kumakura and Kaetsu, 1978).

Entre os vários grupos funcionais característicos da lignina (grupos fenólicos, duplas ligações e grupos carbonila), as carbonilas conjugadas ao anel aromático parecem ser os cromóforos mais efetivos para dar início ao processo de degradação. O pré-tratamento que utiliza peróxido de hidrogênio em meio básico deve seu poder oxidante ao altamente reativo radical hidroxila, gerado na reação do peróxido de hidrogênio com o ânion hidroperóxido. O mecanismo de degradação de lignina por estes agentes não está totalmente esclarecido. Sabe-se, entretanto, que ocorrem reações de hidroxilação, quebra oxidativa de grupos metoxila e abertura de anel (Dziedziela and Kotynska, 1984; Reyes et al., 1998).

\subsection{Fundamentos teóricos das técnicas analíticas}

Há diversos métodos laboratoriais de separação e identificação dos lignocelulósicos, principalmente em materiais lenhosos (eucaliptos) com objetivos voltados à produção de papel e celulose, para tanto existem normas estabelecidas pela Associação Brasileira de Normas Técnicas, ABNT (ABNT-NBR14032,1998) e "American Society for Testing and Materials" (ASTM D1110, ASTM D1109), 1995.

\subsubsection{Determinação de lignina}

A combinação de ácidos e solventes orgânicos facilita o isolamento da lignina e há diversos métodos na literatura, um deles é o espectrofotômetro, que se baseia no fato da lignina ser solúvel em solução de 
brometo de acetila a $25 \%$ em ácido acético glacial, sendo, em seguida, lida a absorbância da mesma no comprimento de onda a $280 \mathrm{~nm}$. A lignina, quando em solução neutra, não é quimiluminiscente, mas apresenta importante emissão quando em meio básico. As espécies responsáveis pela quimiluminescência parecem ser oxigênio singlete e carbonilas excitadas, espécies que têm sido detectadas em espectros de emissão de compostos modelo (ex: vanilina, ácido vanílico, etc.). O método mais utilizado na literatura é o método de Klason que se baseia na extração de polissacarídeos com ácidos fortes, permanecendo um resíduo que, após lavagem, é determinado gravimetricamente como lignina (Elliot, 1969; Koenig, 1999; Glasser and Kelly, 1987; Reyes et al, 1997).

\subsubsection{Determinação de hemicelulose e celulose}

Os métodos químicos de separação da hemicelulose do bagaço da cana-de-açúcar se baseiam na sua solubilidade em solução de hidróxido de sódio a quente $\left(\sim 100^{\circ} \mathrm{C}\right)$. No caso da celulose, o método descrito por Xu et al, 2006, propõe o isolamento da celulose do bagaço da cana-de-açúcar utilizando-se uma mistura de ácido acético a 80\% com ácido nítrico a 70\% na proporção de 10:1, v/v. A amostra é digerida por 20 min. Em banho de óleo à temperatura de 110 a $120^{\circ} \mathrm{C}$ e o precipitado é separado e determinado gravimetricamente como celulose total. Além da celulose total podem ser determinadas as celuloses alfa, beta e gama, que darão informações sobre a fração degradada pela radiação ionizante (ABNT-NBR14032,1998; Fengel and Wegener, 1989):

- Celulose alfa é o tipo usado para designar a porção da celulose que é insolúvel em uma solução de hidróxido de sódio a 17,5\%, à temperatura de $20^{\circ} \mathrm{C}$, em condições determinadas. Representa teor 
verdadeiro de celulose pura do material, isto é, a fração de alta massa molecular. As celuloses que contêm um alto teor de alfacelulose, são chamadas comercialmente em nosso país celulose alfa, "dissolving pulp" ou celulose para "rayon" e são usadas na fabricação de celulose, como acetato, nitrato etc. Geralmente são fabricadas partindo da madeira ou "linter" de algodão, especificamente para estes fins;

- Celulose beta é o termo usado para designar a porção da celulose que é solúvel em uma solução de hidróxido de sódio a 17,5\%, à temperatura de $20^{\circ} \mathrm{C}$, precipitando quando a solução é acidificada. Além da celulose, inclui quase sempre certa quantidade de hemicelulose e celulose degradada;

- Celulose gama é o termo usado para designar a porção da celulose que é solúvel em uma solução de hidróxido de sódio a 17,5\%, à temperatura de $20^{\circ} \mathrm{C}$, não precipitando quando a solução é acidificada. Representa principalmente a fração de hemicelulose.

Os métodos mais comuns de caracterização da estrutura da celulose cristalina são baseados em Raios-X, absorção no infra-vermelho e ressonância magnética nuclear. Entre estas, a difração de Raios-X dá resultados mais diretos da e informações quantitativas (Browning, 1967; Thomsom et al, 2007).

A Espectroscopia do Infra-Vermelho com Transformada de Fourier, FTIR, fornece informações úteis relacionadas a trocas nas ligações de pontes de hidrogênio durante transformações na estrutura cristalina da celulose. A FTIR tem sido extensivamente utilizado em pesquisas de lignocelulósicos pois ela representa um método relativamente fácil de obter informações diretas de alterações que ocorrem durante os vários tratamentos químicos de separação e caracterização de açúcares Ex: Caracterização FTIR 
da degradação de celulose pelo conteúdo de ligação $\mathrm{C}=\mathrm{O}$ vibração em $1740 \mathrm{~cm}^{-1}$ ) (Browning, 1967; Elliot, 1969).

A Ressonância Paramagnética Eletrônica (RPE) é uma técnica consagrada para avaliar a formação e recombinação dos radicais formados após a irradiação. No caso do bagaço da cana-de-açúcar, a maior parte dos radicais formados se recombina rapidamente nas primeiras $5 \mathrm{a} 10 \mathrm{~h}$. A medida destes radicais será útil na identificação do tipo de ligação que foi rompida nos lignocelulósicos.

A análise termogravimétrica (TGA) é usada para monitorar as alterações estruturais dos polímeros lignocelulósicos através da degradação térmica. A análise térmica da madeira apresenta dois picos exotérmicos, em virtude da soma das decomposições dos diversos componentes, tais como a celulose, hemicelulose, lignina, polissacarídeos etc. A pirólise da lignina é muito mais lenta que a da celulose. Amostras de madeira da aroeira tratadas a $230^{\circ} \mathrm{C}, 310^{\circ} \mathrm{C}$ e $450^{\circ} \mathrm{C}$, apresentaram na curva DSC, dois picos. O primeiro corresponde à queima de celulose e o segundo, à queima de lignina. Para pirólise em $950^{\circ} \mathrm{C}$ surge apenas um pico em torno de $450^{\circ} \mathrm{C}$, correspondente à oxidação do produto da pirólise completa da lignina e da celulose (Tsujiyama, 2000).

Análises cromatográficas líquida e gasosa são uma ferramenta importante para controlar o grau de clivagem da lignina, hemicelulose e celulose. O controle da clivagem da lignina pode ser avaliado pela análise cromatográfica dos compostos fenólicos, a partir das análises destes compostos, após extração com solventes orgânicos. Utilizando-se a cromatografia líquida de alta eficiência, CLAE, pode-se avaliar os açúcares liberados pela clivagem da hemicelulose (xilose, arabinose, galactose, glucose e manose) e da celulose (glicose). A extração é realizada diretamente no bagaço da cana-de-açúcar com água quente. 


\subsection{Objetivo}

Este trabalho é parte dos projetos intitulados "Studies of cellulose hydrolysis from sugarcane bagasse to production of ethanol biofuel and new polysaccharides polymers applying ionizing radiation", financiado pela AIEA (Research Contract In. 14709), e "Estudo da hidrólise da celulose do bagaço de cana pelo processo de oxidação avançada por radiação ionizante para obtenção do biocombustível etanol" (FAPESP 2007/05679-0) e tem como objetivo avaliar a eficiência da irradiação com feixe de elétrons como um prétratamento do bagaço de cana para o processo enzimático de hidrólise de celulose, otimizando a dose absorvida aplicada de tal forma que, seja a mínima necessária, para rompimento de ligações químicas na lignina e na hemicelulose sem degradar a celulose. Para tanto, foram necessárias algumas etapas, como:

- Estudar as características físico-químicas do bagaço para adequação aos sistemas de irradiação;

- Adaptar as técnicas analíticas para avaliação da clivagem da hemicelulose, da lignina e da celulose em diferentes doses absorvidas;

- Aplicar o processo enzimático de hidrólise de celulose no bagaço irradiado. 


\subsection{PARTE EXPERIMENTAL}

A parte experimental será descrita em três etapas que são a coleta de amostras de bagaço de cana, o processamento por feixe de elétrons e os ensaios para avaliação dos efeitos da radiação ionizante.

\subsection{Coleta de amostras de bagaço de cana}

As amostras do bagaço da cana-de-açúcar foram coletadas na Fazenda Iracema em Piracicaba/SP com o apoio do Centro de Tecnologia Canavieira (CTC). Foram realizadas duas coletas, a primeira em setembro/2007 correspondeu a um bagaço estocado a cerca de 20 dias, pois a usina estava parada em virtude de chuvas no período. Este bagaço estava mais seco pela exposição ambiental e foi denominado de "Bagaço A".

A segunda coleta de amostra foi realizada em abril/2008 e correspondeu a um bagaço recém processado, pois a usina estava em funcionamento, como mostrada na foto da Figura 7. Este bagaço apresentavase mais úmido e fresco e foi denominado de "Bagaço B".

Para homogeneizar o tamanho das fibras, as amostras foram peneiradas utilizando peneira com furos de $4,00 \mathrm{~mm}$ de diâmetro. $\mathrm{O}$ teor de umidade das amostras foi determinado pelo método gravimétrico, sendo utilizadas $10 \mathrm{~g}$ de cada amostra, aquecendo-as a $60^{\circ} \mathrm{C}$ até obtenção de peso constante, numa estufa. Para calcular a espessura da camada a ser irradiada, foi determinada a densidade aparente das amostras pelo método gravimétrico. 


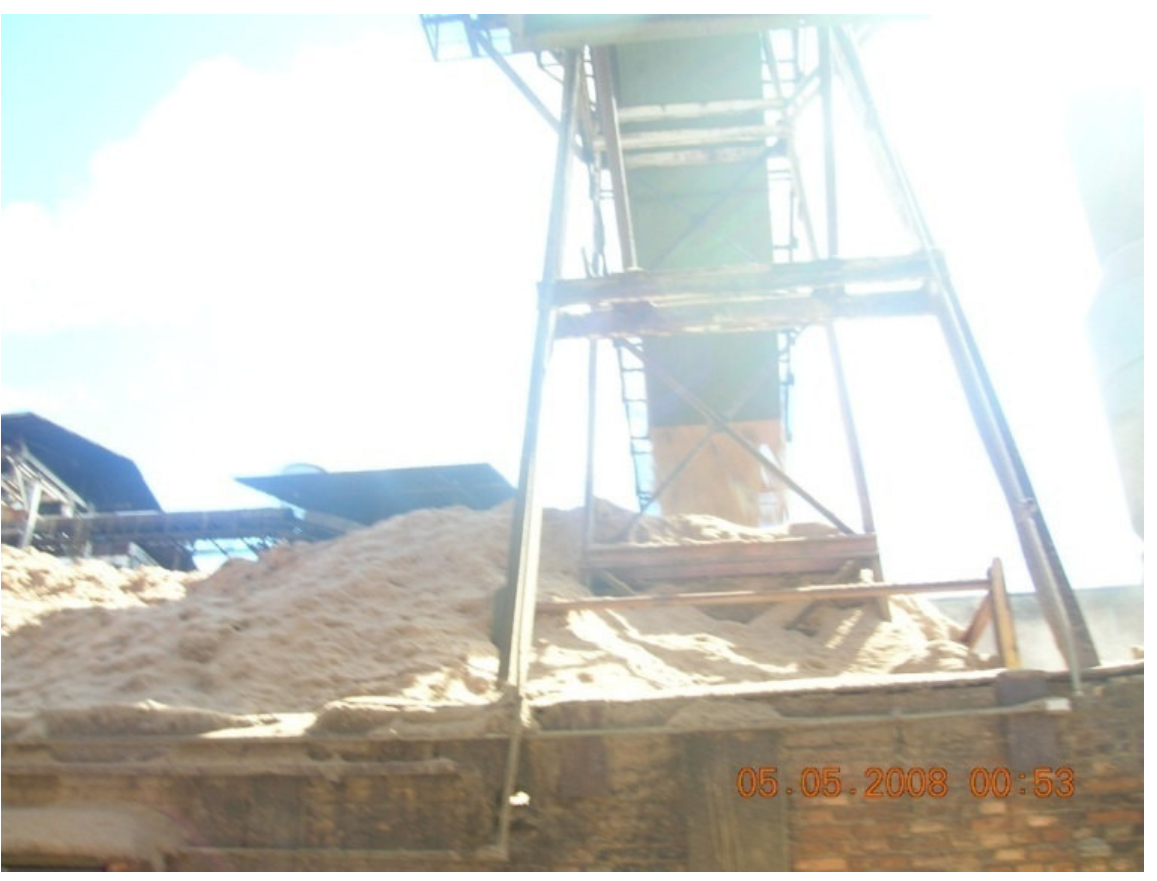

FIGURA 7. Local da coleta do bagaço de cana B na Fazenda Iracema, Piracicaba, SP

\subsection{Processamento por feixe de elétrons}

As amostras do bagaço de cana foram irradiadas no Centro de Tecnologia das Radiações do IPEN, utilizando-se o Acelerador Industrial de Elétrons de $1,5 \mathrm{MeV}$ de energia e $25 \mathrm{~mA}$ da Radiation Dynamics Inc., USA. Os parâmetros de irradiação usados foram $2,0 \mathrm{~cm}$ de espessura da amostra, $112 \mathrm{~cm}(94,1 \%)$ de varredura e $6,72 \mathrm{~m} / \mathrm{min}$ de velocidade da esteira.

A irradiação foi realizada em sistema de bateladas, em bandejas de vidro tipo "pyrex" (Figura 8). O bagaço de cana da primeira amostragem, Bagaço A, foi irradiado com doses absorvidas de 20 kGy, 50 kGy, 100 kGy, 150 kGy e 200 kGy, após conclusão e avaliação dos ensaios referentes a esta amostragem, definiu-se as doses aplicadas na segunda amostragem, Bagaço B, que foram 5 kGy, 10 kGy, 20 kGy, 30 kGy, 50 kGy, 70 kGy, 100 kGy e $150 \mathrm{kGy}$. 


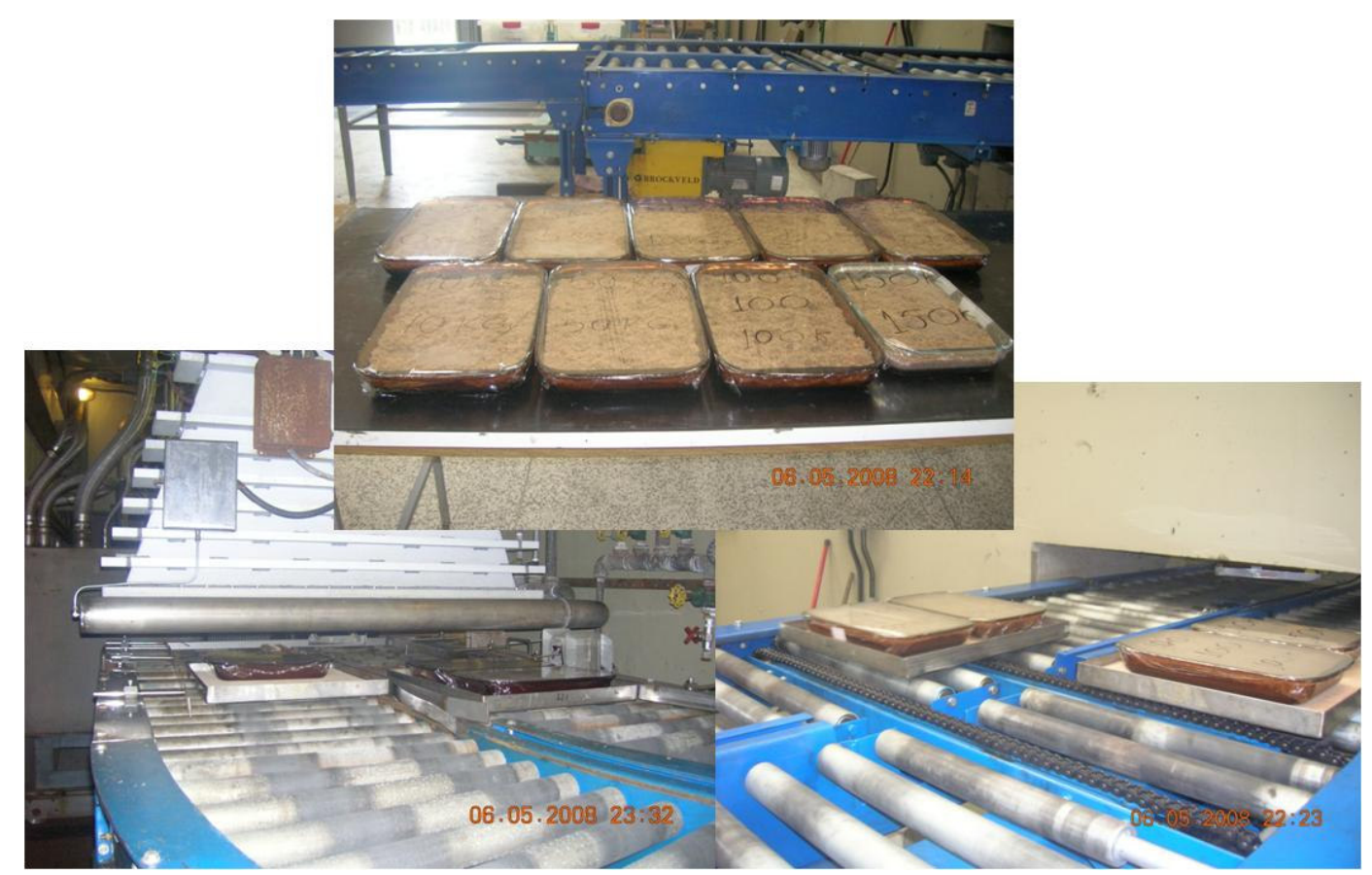

FIGURA 8. Sistema de irradiação de amostras no acelerador de feixe de elétrons

\subsection{Ensaios para avaliação dos efeitos da radiação ionizante}

Após a irradiação todas as amostras foram secas em estufa, trituradas e separadas pelo processo de tamisação. Em virtude da presença de areia nas amostras, foi selecionada a faixa de partículas entre as peneiras de diâmetro $1,00 \mathrm{~mm}$ e $0,42 \mathrm{~mm}$. Foram realizados ensaios de solubilidade do bagaço da cana-de-açúcar, determinação do teor de lignina, determinação de celulose total, alfa e beta. Em uma terceira etapa, a celulose foi caracterizada pela análise de espectroscopia de Infravermelho e microscopia eletrônica e os ensaios referentes à hidrólise enzimática. 


\subsubsection{Solubilidade a quente}

Este ensaio foi realizado conforme a norma ASTM D1110-84. A 2,00 g da amostra foram adicionados $100 \mathrm{ml}$ de água destilada e foram deixadas em refluxo por 3 horas a $100^{\circ} \mathrm{C}$. Após resfriamento, as amostras foram filtradas a vácuo e secas em estufa por 24 horas. A solubilidade das amostras foi determinada pelo método gravimétrico.

\subsubsection{Solubilidade em Hidróxido de Sódio 1\%}

Este ensaio foi realizado conforme a norma ASTM D1109-84. A 2,00g de amostra foram adicionados $100 \mathrm{ml}$ da solução de hidróxido de sódio $1 \%(\mathrm{p} / \mathrm{v})$ e levadas ao banho-maria por 1 hora. Após resfriamento, as amostras foram filtradas a vácuo e lavadas com $100 \mathrm{ml}$ de água destilada e 50 $\mathrm{ml}$ da solução de ácido acético $10 \%$ (v/v) para neutralização. As amostras foram secas em estufa por 24 horas. A solubilidade das amostras foi determinada pelo método gravimétrico.

\subsubsection{Teor de Lignina}

No presente trabalho, adotou-se o método de Klason modificado (Gomide and Demuner, 1986), possibilitando o uso de uma menor quantidade de material e considerável diminuição do tempo necessário para a determinação do teor de lignina. A 0,3 g de amostra foram adicionados 3,0 ml de ácido sulfúrico concentrado. Após 1 hora, as amostras foram transferidas para balão de destilação. Foram adicionados $85 \mathrm{ml}$ de água destilada e aquecidas em refluxo por 1 hora a $60^{\circ} \mathrm{C}$. Após resfriamento, as amostras foram filtradas a vácuo, secas em estufa por 24 horas. O teor de lignina foi determinado pelo método gravimétrico. 
Para avaliar a degradação da lignina após a irradiação, foi determinado o teor de compostos fenólicos liberados. $\mathrm{O}$ fenol foi determinado após extração com solução de hexano/diclorometano 1:1 (v/v) e análise por cromatografia gasosa. Foi utilizado um Cromatógrafo a Gás da Shimadzu, modelo CG-17A, nas condições:

- temperatura de injeção de $200^{\circ} \mathrm{C}$,

- temperatura de detecção: $300^{\circ} \mathrm{C}$,

- Fluxo: $10 \mathrm{~mL} / \mathrm{min}$., $\mathrm{N}_{2}$. Pressão de controle (EPC): $37 \mathrm{kPa}$,

- coluna DB5 (30m x 0,25 mm I.D.) na temperatura inicial de $50^{\circ} \mathrm{C}$ até $150^{\circ} \mathrm{C}\left(10^{\circ} \mathrm{C} / \mathrm{min}\right)$, elevada a $300^{\circ} \mathrm{C}\left(15^{\circ} \mathrm{C} / \mathrm{min}\right)$, mantida por 5 minutos.

\subsubsection{Celulose total, alfa e beta}

Primeiramente foi determinada a celulose total (Fengel and Wegener, 1989). Em $5 \mathrm{~g}$ de amostra foi adicionada uma mistura de ácido acético $80 \%$ com ácido nítrico $70 \%$ na proporção de 10:1, v/v. As amostras foram digeridas por 20 minutos em refluxo a $60^{\circ} \mathrm{C}$. Após resfriamento, as amostras foram filtradas a vácuo e o precipitado foi separado e determinado gravimetricamente, como celulose total.

Em uma segunda etapa foram determinados os teores de celuloses alfa e beta, conforme a norma ABNT NBR 14032-98. Para tanto, em 1,50 g de amostra deslignificada foram adicionados $100 \mathrm{ml}$ de hidróxido de sódio 17,5\% (m/v). Após 30 minutos, foram adicionados $100 \mathrm{ml}$ de água destilada e

permaneceu mais 30 minutos em repouso, o precipitado foi filtrado em cadinho de vidro. $\mathrm{O}$ filtrado foi reservado em frasco limpo e seco com tampa esmerilhada para posterior determinação da celulose alfa e beta. 
Para determinação da celulose alfa, $10 \mathrm{ml}$ do filtrado anterior foi transferido para um frasco do tipo "erlenmeyer" e foram adicionados $10 \mathrm{ml}$ de solução de dicromato de potássio $0,5 \mathrm{~N}(\mathrm{~m} / \mathrm{v})$ e $30 \mathrm{ml}$ de ácido sulfúrico concentrado. Após 15 minutos em repouso, foram adicionadas à solução, 4 gotas da solução indicadora de ferroína $(\mathrm{m} / \mathrm{v})$ e titulada com solução de sulfato ferroso amoniacal $0,1 \mathrm{~N}(\mathrm{~m} / \mathrm{v})$ até o aparecimento de uma coloração avermelhada.

Para determinação da celulose beta, foram transferidos $50 \mathrm{ml}$ do filtrado para um balão volumétrico e adicionados $50 \mathrm{ml}$ da solução de ácido sulfúrico $3 \mathrm{~N}(\mathrm{v} / \mathrm{v})$. A solução permaneceu em repouso por 12 horas a $7^{\circ} \mathrm{C}$ para que ocorra a coagulação da celulose beta. Após este período as amostras foram filtradas em papel de filtro a vácuo, secas em estufa a $60^{\circ} \mathrm{C}$ por 24 horas e determinada pelo método gravimétrico.

\subsubsection{Espectroscopia do Infravermelho}

Para a análise de espectroscopia do infravermelho foi utilizado um Espectrofotômetro Interferométrico da marca BOMEM, modelo MB-SERIES do Centro de Biotecnologia do IPEN. Para caracterização da molécula de celulose do Bagaço de Cana B foi necessário a preparação de pastilhas das amostras. Para tanto, cada pastilha foi preparada de modo a conter uma mistura de brometo de potássio (pó) e amostras do bagaço não-irradiado e irradiado nas diferentes doses absorvidas.

\subsubsection{Microscopia Eletrônica de Varredura (MEV)}

A análise microscópica estrutural da fibra do Bagaço de Cana B foi realizada por um microscópio eletrônico da marca Philips, modelo XL30, em 
um aumento de 1000x (vezes) do Laboratório de Microscopia do Centro de Ciência e Tecnologia dos Materiais do IPEN. Foram analisadas três amostras, com doses absorvidas de $10 \mathrm{kGy}$ e $50 \mathrm{kGy}$ e a não-irradiada. Para a preparação das amostras, uma pequena fração foi fixada em porta-amostra de alumínio e recoberta com ouro para visualização da topografia das amostras.

\subsection{Hidrólise enzimática}

Os ensaios de hidrólise enzimática das amostras irradiadas e nãoirradiada foram realizados nos laboratórios do Centro de Tecnologia Canavieira, nas seguintes condições:

- Massa total no reator $=50 \mathrm{~g}$;

- $\quad$ Carga de sólidos no reator $=8 \%$ (base seca);

- Carga de enzima no reator: Celuclast $1,5 \mathrm{~L}=5 \mathrm{FPU} / \mathrm{g}-$ celulose;

- Beta-glicosidase $=0,5 \%(\mathrm{p} / \mathrm{p})$.

Celuclast é um concentrado comercial de enzima preparado do fungo Trichoderma reesei da Novozymes, Bagsvaerd, Denmark).

Juntamente com a hidrólise enzimática, foi realizado no CTC o ensaio para verificar a variação do teor de umidade com o tempo de incubação para as amostras irradiadas e não irradiada. Para esse ensaio foi utilizado um sistema automático de aquecimento e medida de umidade. 


\section{RESULTADOS E DISCUSSÃO}

Os resultados serão apresentados em duas etapas que são os efeitos da radiação no bagaço de cana, tais como, a caracterização físico-química e os efeitos da radiação na estrutura do bagaço de cana e os efeitos na hidrólise enzimática propriamente dita.

\subsection{Efeitos do processamento por feixe de elétrons nas características físico-químicas do bagaço de cana}

As amostras de bagaço de cana A apresentaram densidade aparente de $0,14 \mathrm{~g} / \mathrm{cm}^{3}$ e de bagaço de Cana B $0,16 \mathrm{~g} / \mathrm{cm}^{3}$ após separação granulométrica, o que possibilitou a irradiação de uma camada de amostra com 2,8 cm de espessura para Cana A e 2,4 cm para Cana B.

$\mathrm{O}$ teor de umidade na amostra do bagaço de cana da primeira coleta antes da irradiação foi de $55,7 \%$ e da segunda coleta foi de $64,2 \%$.

Os resultados de variação do teor de umidade com a dose de radiação aplicada são apresentados na Figura 9 para o Bagaço B. Observa-se que, após a irradiação, não houve perda significativa de umidade nas amostras, mesmo no caso da maior dose aplicada de $150 \mathrm{kGy}$. Este manutenção de umidade confirma que não houve aquecimento das amostras durante o processamento.

Os resultados do ensaio de umidade realizado no CTC juntamente com a hidrólise enzimática são apresentados na Figura 10. As amostras não irradiada e irradiadas com doses absorvidas de até $20 \mathrm{kGy}$ apresentaram comportamento semelhante, mas a irradiadas com 100 kGy e 150 kGy 
apresentaram mudança de comportamento em relação as demais doses no intervalo entre 2 e 14 minutos, mas acima deste tempo o comportamento foi semelhante para todas as doses. A manutenção da umidade é desejável no caso da hidrólise enzimática, portanto este é um fator positivo do processamento com feixe de elétrons.

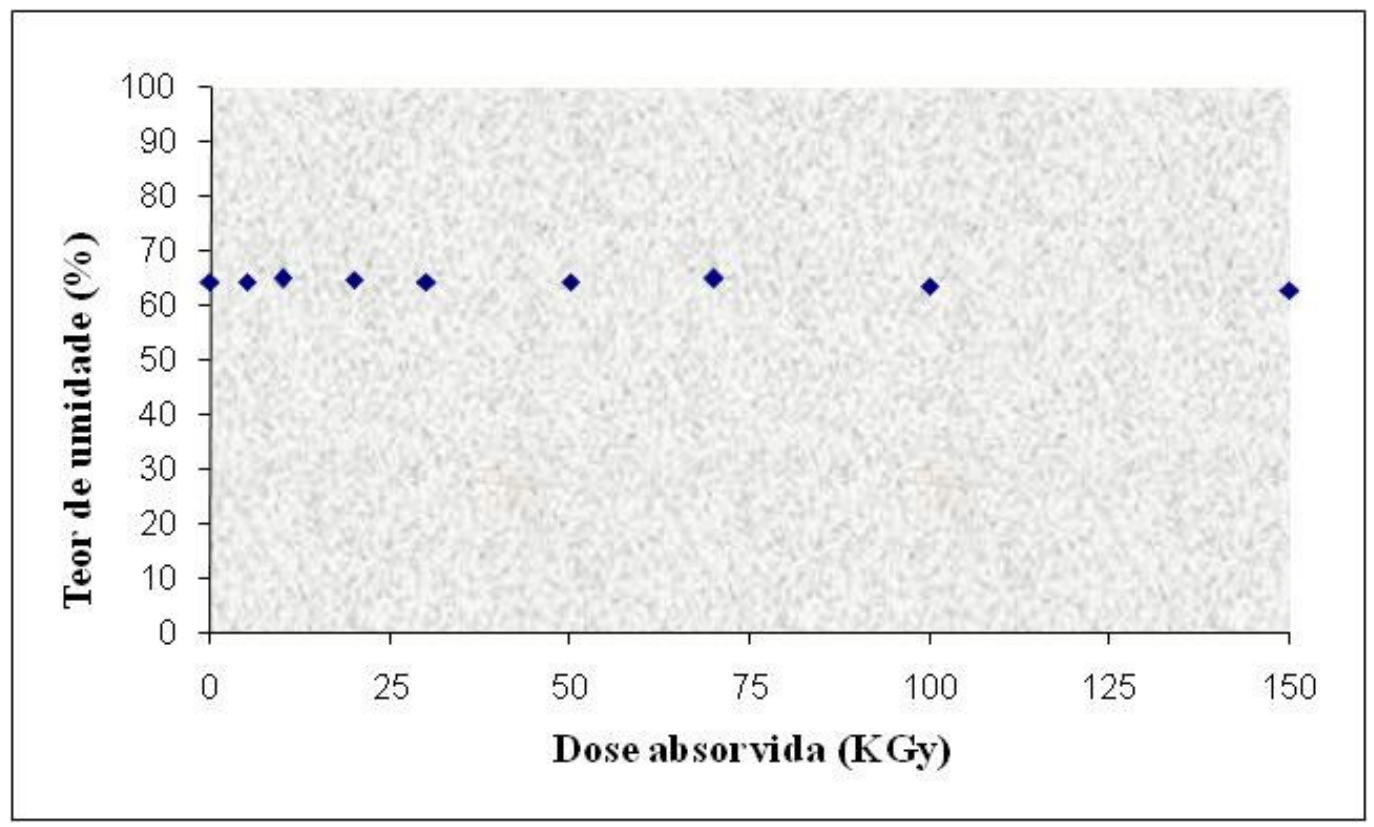

FIGURA 9. Variação do teor de umidade pela dose absorvida de radiação na amostra do Bagaço B

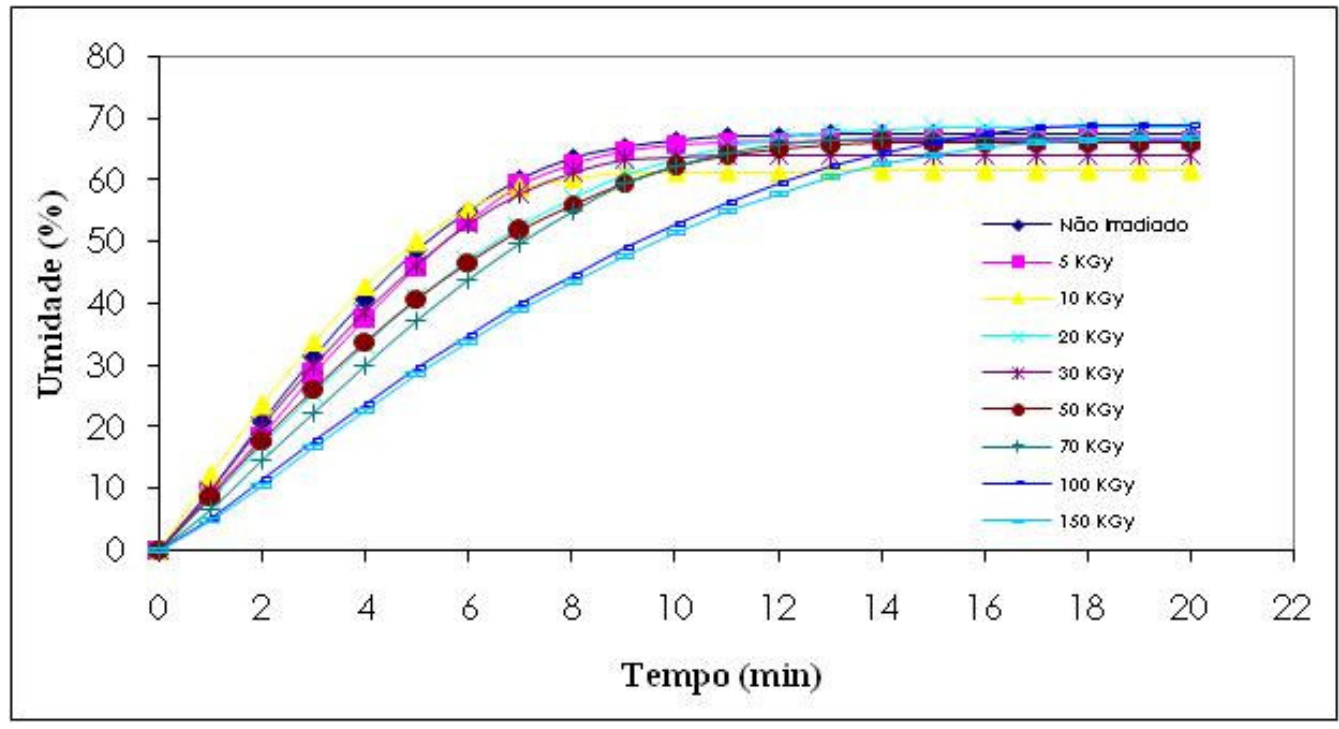

FIGURA 10. Variação do teor de umidade pelo tempo de aquecimento nas amostras do Bagaço B após irradiação em diferentes doses absorvidas 


\subsubsection{Lignina}

Os resultados de teores de lignina nas amostras de bagaço de cana antes e após o processamento por feixe de elétrons, são apresentados nas Figuras 11 e 12.

O teor de lignina apresentou uma ligeira queda após a irradiação com a dose máxima de $200 \mathrm{kGy}$ no caso do Bagaço A, mas no caso da amostra B, cuja dose máxima foi de $150 \mathrm{kGy}$, não houve variação significativa.

Os resultados de determinação de fenol por cromatografia gasosa, antes e após a irradiação, são apresentados na Figura 13 e 14 para o bagaço de cana A e B, respectivamente. Estes resultados demonstram que houve liberação de fenol com o aumento da dose de radiação aplicada até o máximo de 100 kGy. A partir de 100 kGy, houve uma diminuição do teor de fenol o que pode ter sido causado pela ação da radiação, levando a sua degradação. Esses resultados confirmam que, embora o teor de lignina tenha apresentado pouca variação com a irradiação, esta provocou rompimento em ligações químicas levando à liberação de compostos fenólicos. 


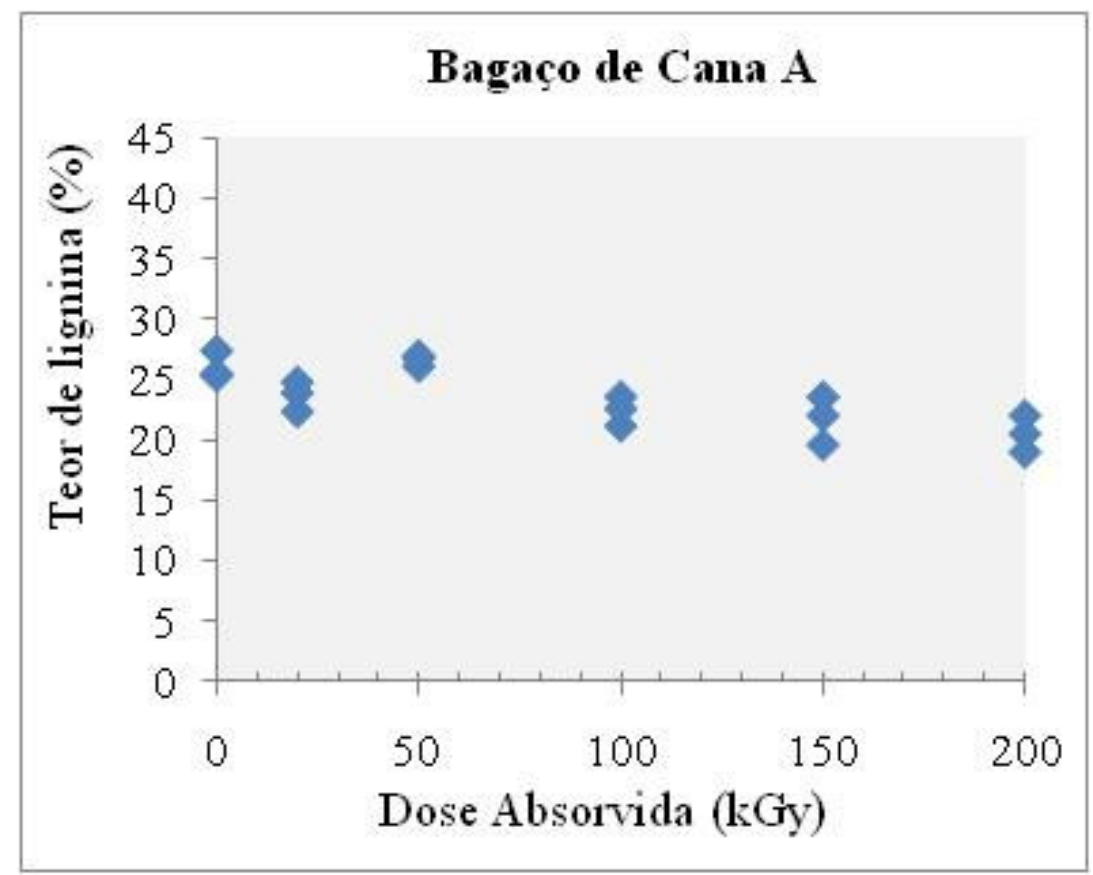

Figura 11. Variação do teor de lignina (\%) na amostra de Bagaço A após irradiação em diferentes doses absorvidas

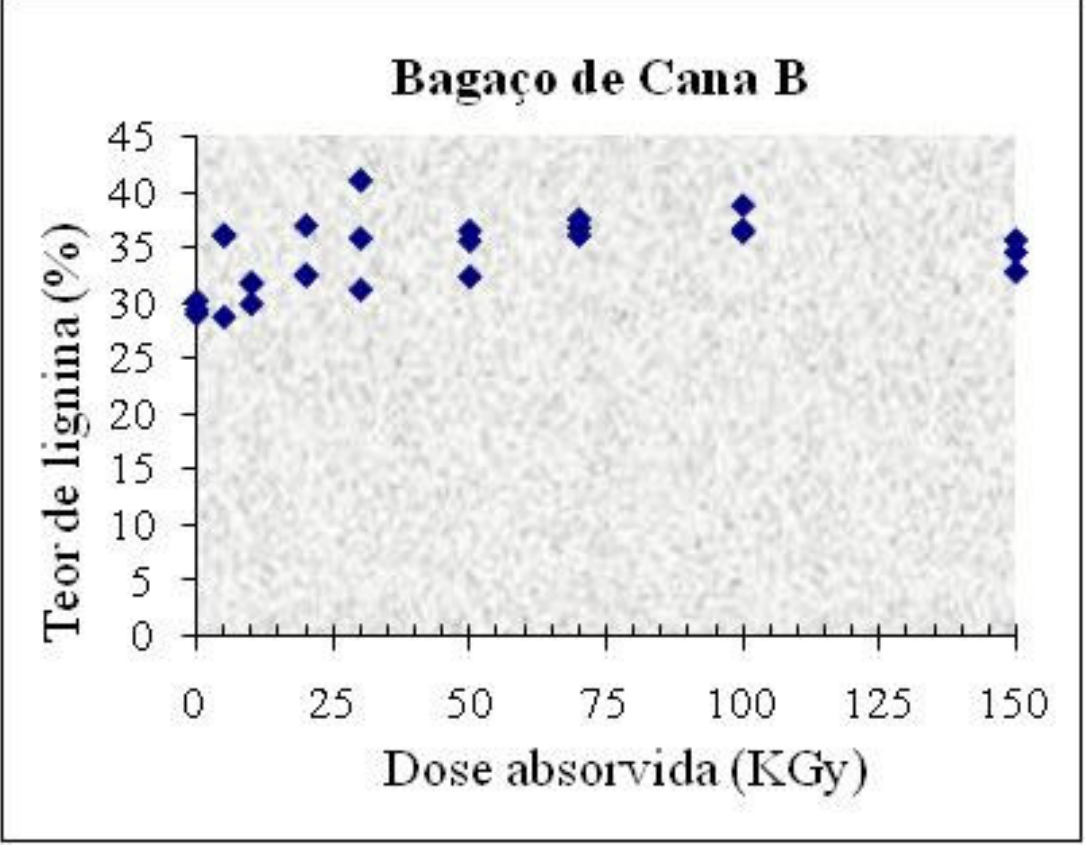

Figura 12. Variação do teor de lignina (\%) na amostra de Bagaço B após irradiação em diferentes doses absorvidas 


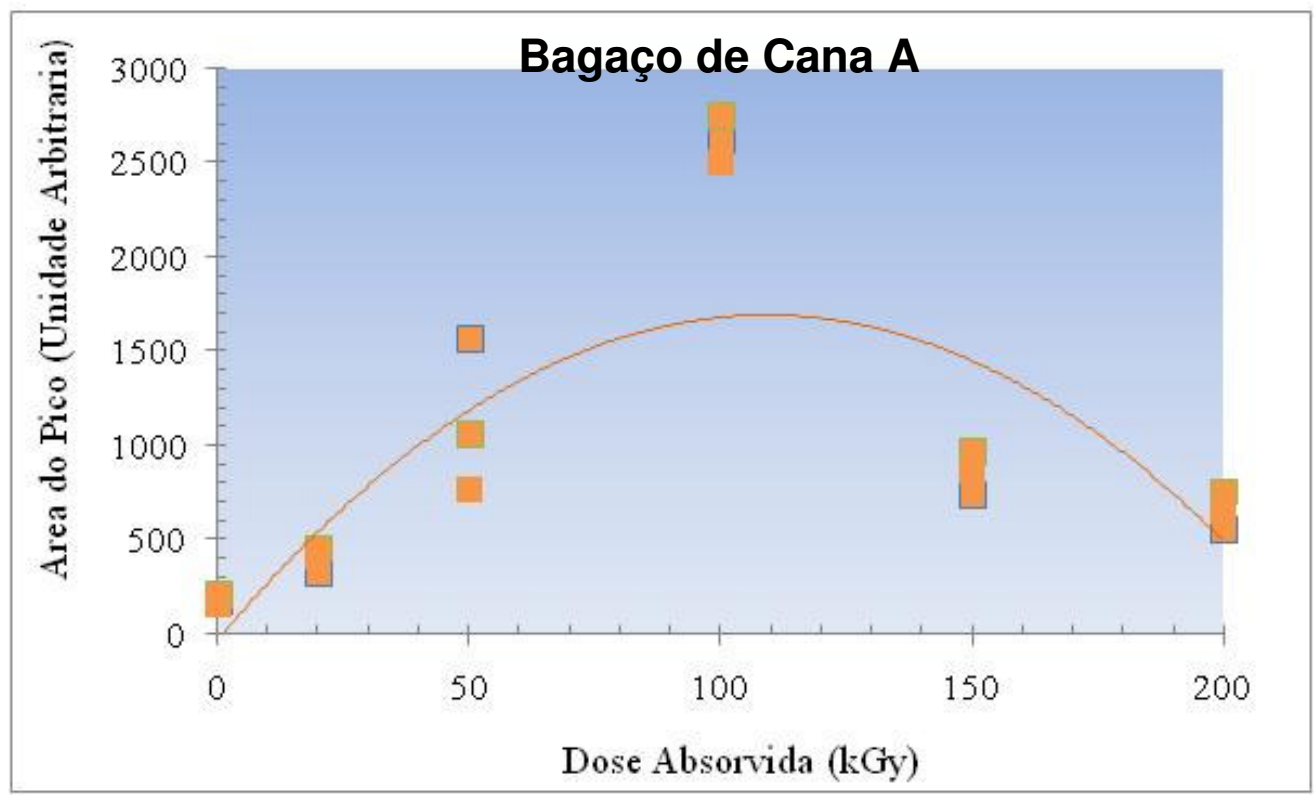

Figura 13. Liberação de fenol na amostra de Bagaço A após irradiação em diferentes doses absorvidas

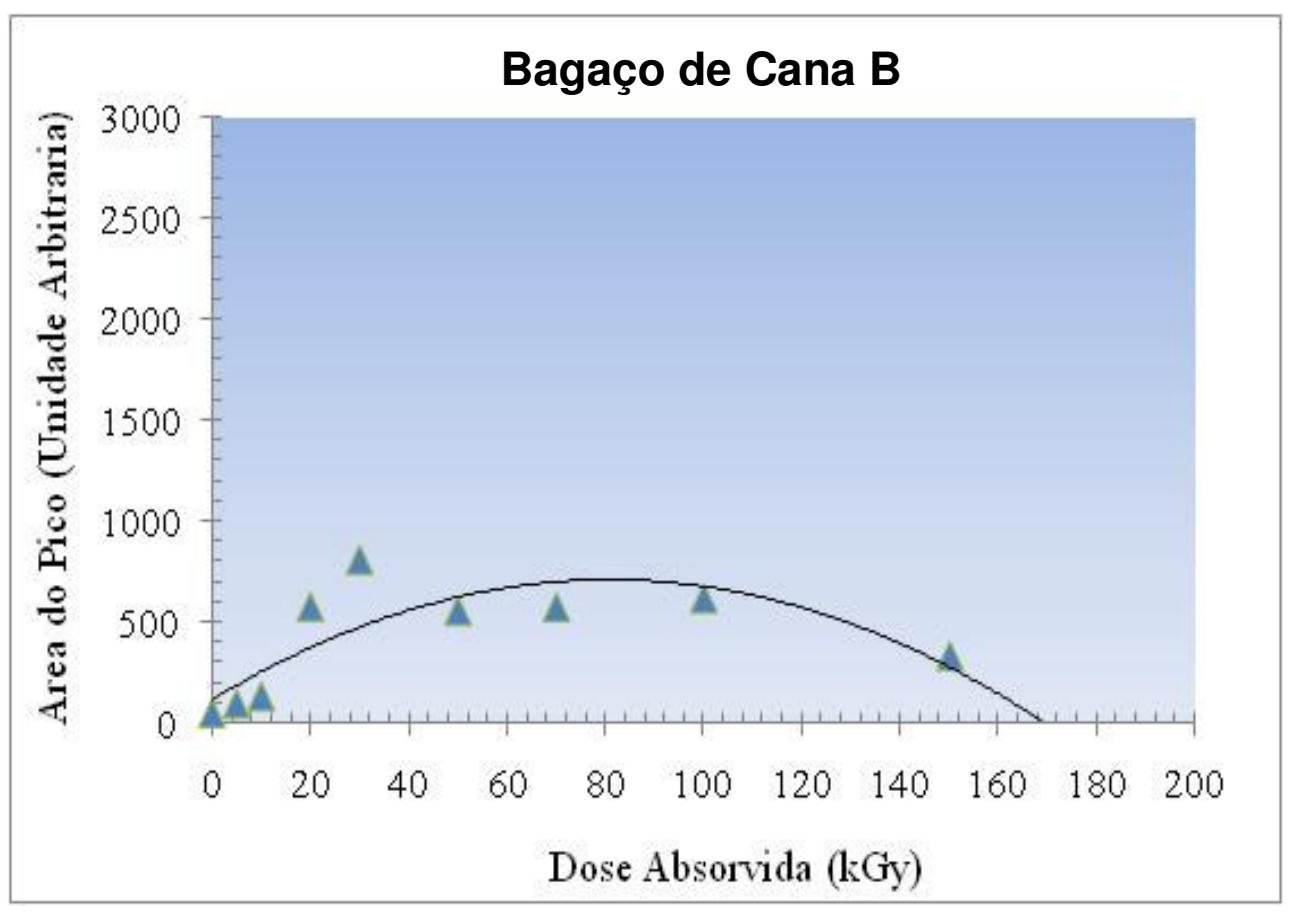

Figura 14. Liberação de fenol na amostra de Bagaço B após irradiação em diferentes doses absorvidas 


\subsubsection{Açúcares solúveis}

A fração solubilizada a quente do bagaço representa os açúcares solúveis na amostra que são originados da clivagem das moléculas de celulose e hemicelulose do bagaço de cana. Na Figura 15 são apresentados os resultados de teores de açúcares solúveis em relação à dose de radiação aplicada para as amostras do Bagaço A. Houve um aumento de cerca de 10\% do teor destes açúcares para a dose máxima de 200 kGy, comparado a amostra não-irradiada. Uma observação importante a ser feita é que o início da liberação de açúcares se deu com doses superiores a $50 \mathrm{kGy}$, este foi um fato positivo pois o objetivo do pré-tratamento foi facilitar a ação das enzimas hidrolíticas e não causar a degradação de celulose e perda dos açúcares. A partir deste resultado optou-se por utilizar doses menores como 5 e 10 kGy e minimizar a dose máxima de 200 kGy utilizada no bagaço de Cana A para 150 kGy na segunda amostragem para efeitos de comparações.

No caso do Bagaço B, cujos resultados de açúcares liberados são apresentados na Figura 16, houve uma liberação de cerca de $8 \%$ para uma dose de 150 kGy em relação a amostra não-irradiada, o que foi similar ao Bagaço A, mas doses absorvidas menores que $25 \mathrm{kGy}$ apresentaram aumento desses acúcares. 


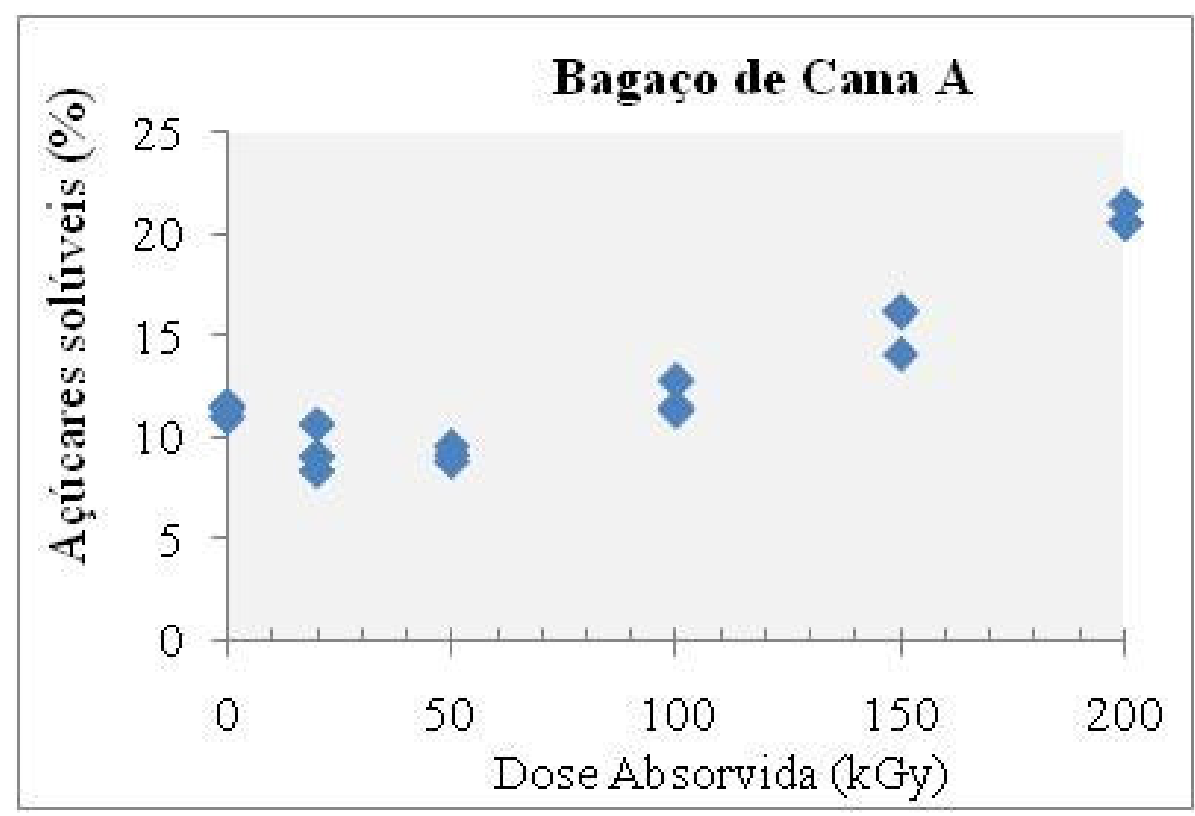

Figura 15. Variação do teor de açúcares livres na amostra de Bagaço A após irradiação em diferentes doses absorvidas

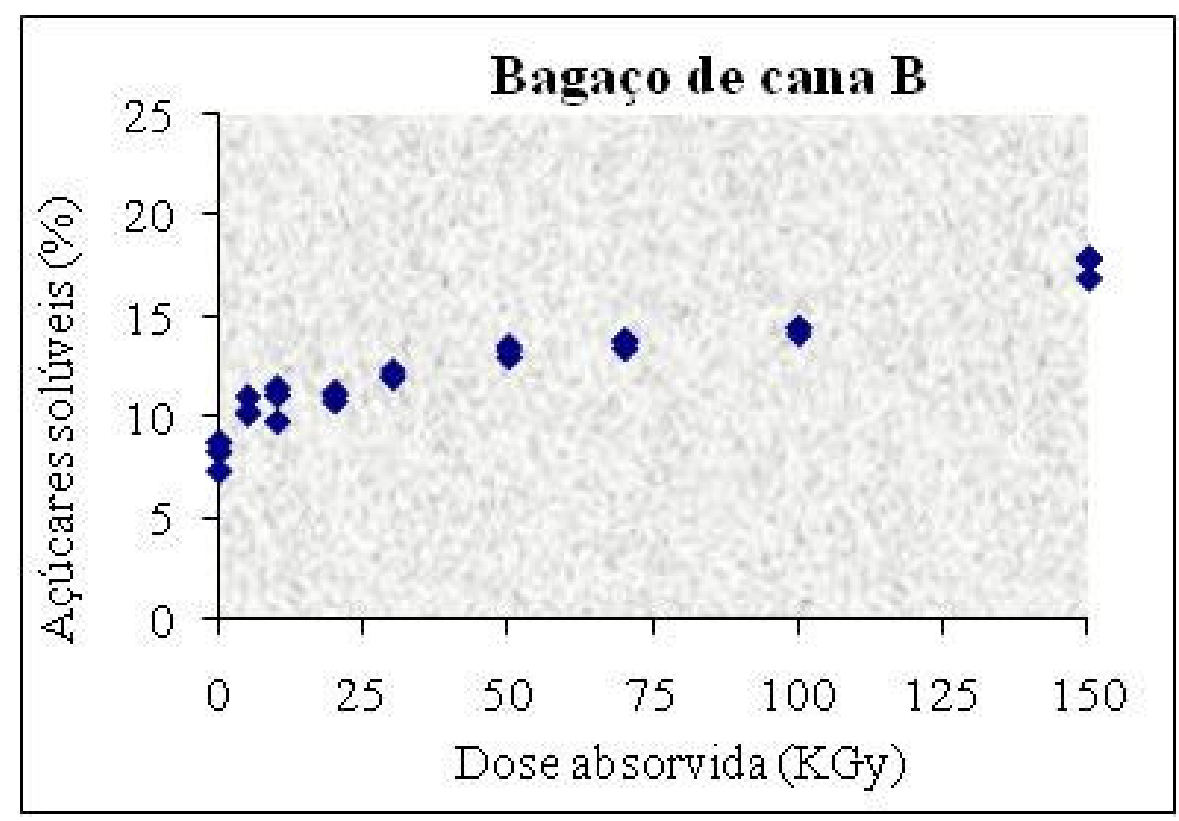

Figura 16. Variação do teor de açúcares livres na amostra de Bagaço B após irradiação em diferentes doses absorvidas 


\subsubsection{Hemicelulose}

Os resultados de determinação do percentual de hemicelulose também mostraram um comportamento de proporcionalidade, ou seja, à medida que se aumenta a dose absorvida aumenta-se também a percentagem da extração de hemicelulose, chegando a $40 \%$ no caso da dose de 200 kGy para amostra A e $20 \%$ para dose de $150 \mathrm{kGy}$ e amostra B . Sendo que abaixo de $25 \mathrm{kGy}$ a liberação foi menos significativa nos dois casos. Estes resultados são apresentados nas Figuras 17 e 18 com o teor de hemicelulose em relação à dose de radiação aplicada para as amostras de bagaço de cana A e B, respectivamente.

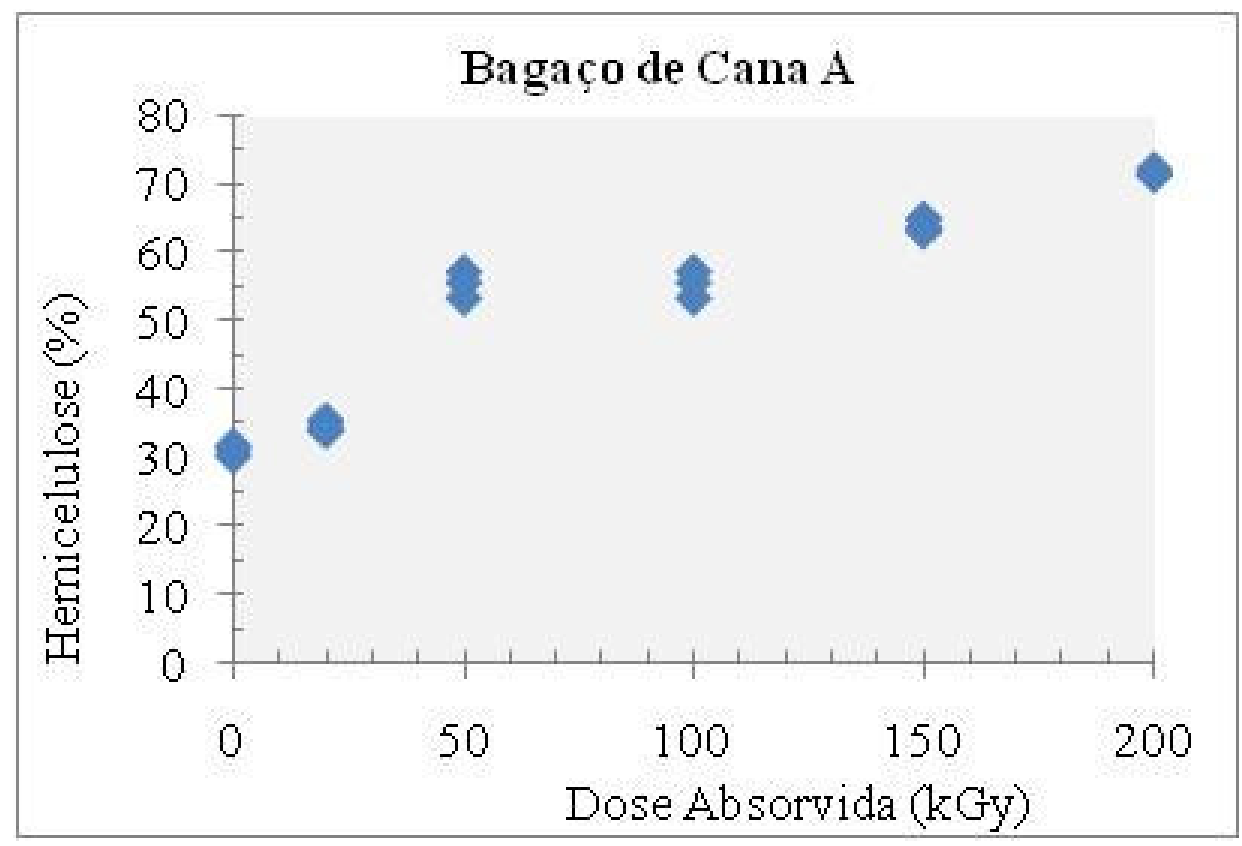

Figura 17. Variação do teor de hemicelulose na amostra de Bagaço A após irradiação em diferentes doses absorvidas 


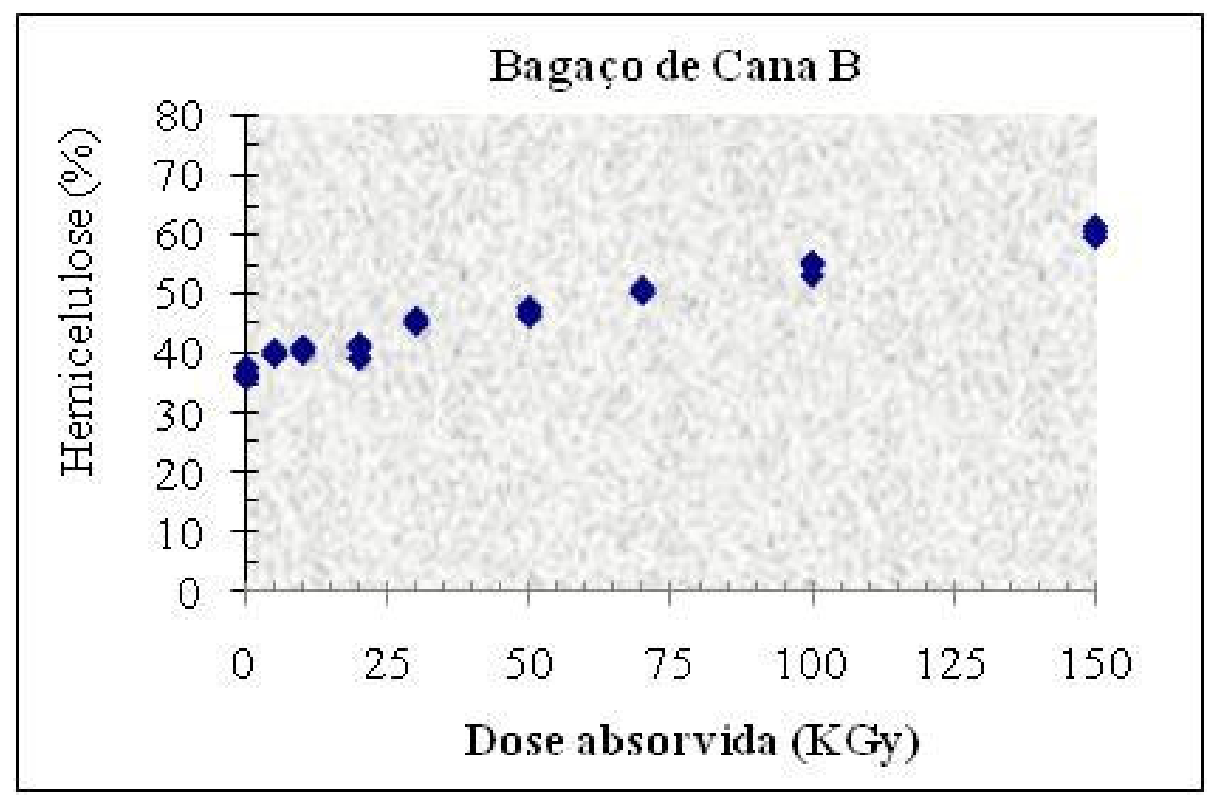

Figura 18. Variação do teor de hemicelulose na amostra de Bagaço B após irradiação em diferentes doses absorvidas

\subsubsection{Celulose}

A amostra de bagaço de cana A apresentou um valor médio de celulose total de $46,9 \pm 0,6 \%$ e a amostra de bagaço de cana B apresentou um

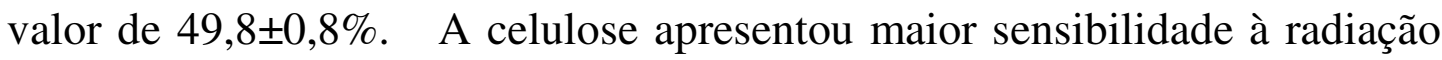
que os outros lignocelulósicos, tanto no caso da amostra A como no caso da amostra B houve uma redução significativa no teor de celulose alfa que representa a celulose de peso molecular elevado. Nos dois casos com uma dose absorvida de 100 kGy houve uma redução de cerca de $99 \%$ da celulose íntegra, como pode ser observado pelos gráficos da Figuras 19 e 20.

No caso do Bagaço B a redução foi maior para doses menores do que o Bagaço A, $20 \mathrm{kGy}$ de dose absorvida reduziu cerca de $50 \%$ da celulose do Bagaço A e cerca de 70\% do Bagaço B. 


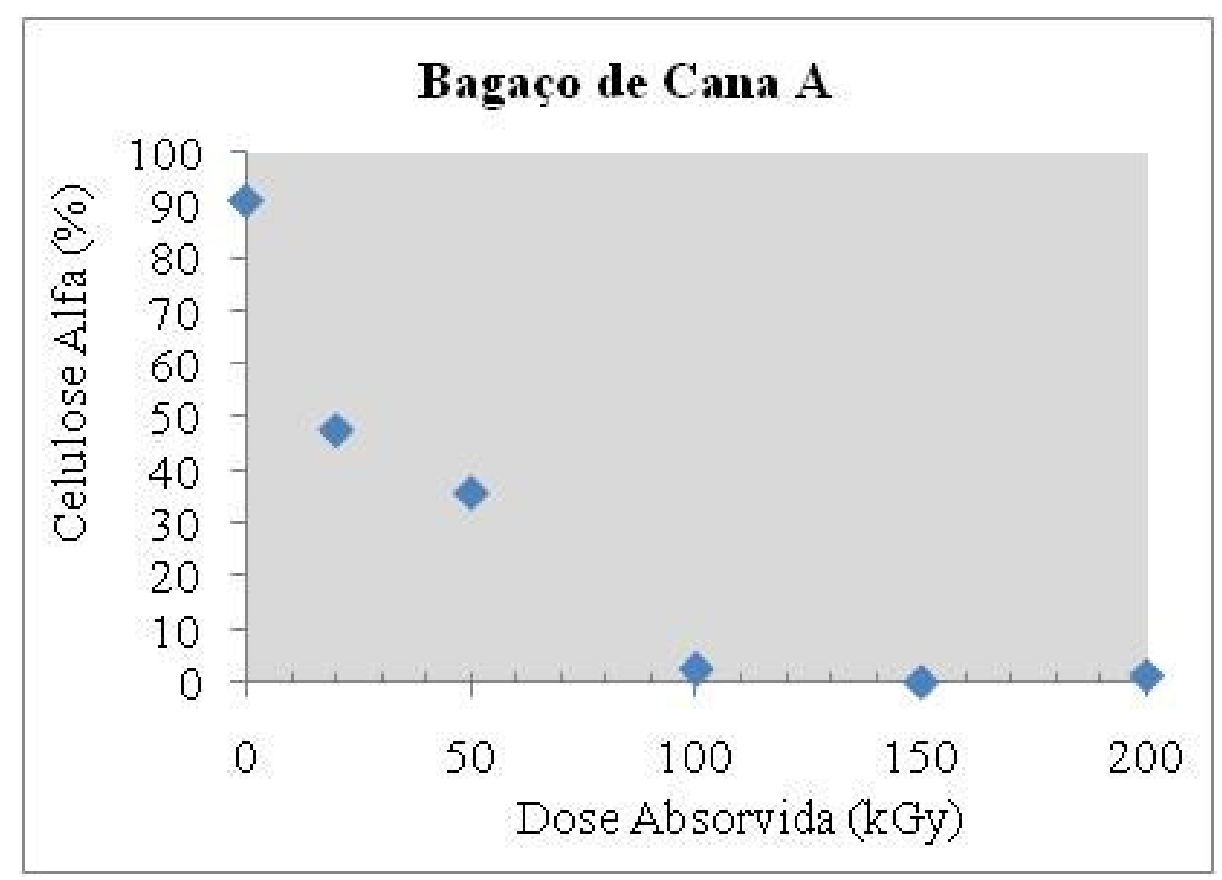

Figura 19. Variação do teor de celulose de alto peso molecular na amostra de Bagaço A após irradiação em diferentes doses absorvidas

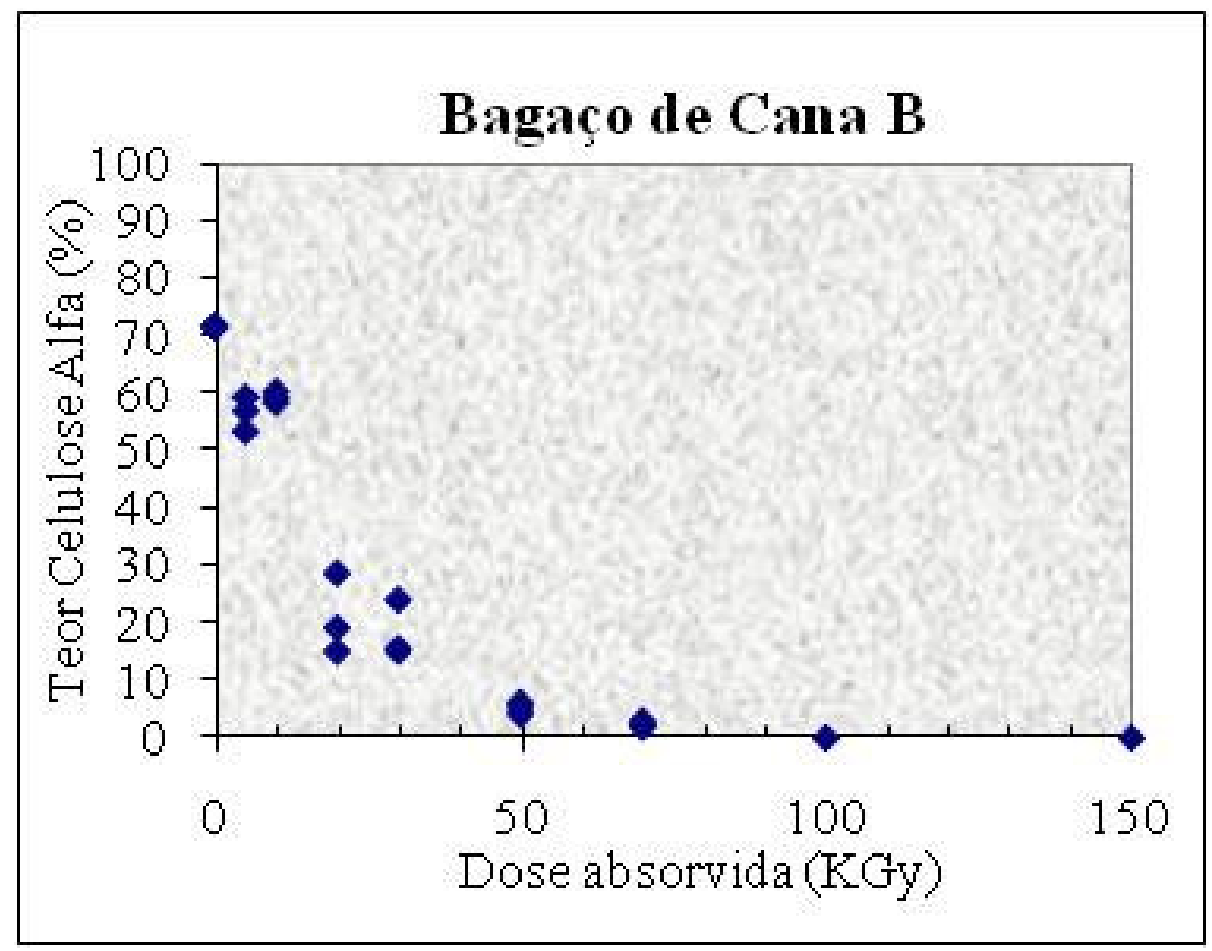

Figura 20. Variação do teor de celulose de alto peso molecular na amostra de Bagaço B após irradiação em diferentes doses absorvidas 
Os resultados de determinação de celulose beta que representa pedaços menores do polímero confirmaram os resultados obtidos com celulose alfa, ou seja, as reduções na celulose alfa (Figuras 19 e 20) foram acompanhadas pelo aumento de celulose degradada (Figuras 21 e 22). Mas nesse caso houve uma alteração no comportamento da curva a partir de 100 kGy para o Bagaço A e a partir de 50 kGy para o Bagaço B, ou seja, as curvas mudaram a tendência.

Para explicação deste fato apresenta-se as fotos da Figura 23, que demonstram a formação do precipitado de celulose beta para o Bagaço A. Nota-se que a aparência do precipitado de 200 kGy após a secagem é similar ao precipitado de $50 \mathrm{kGy}$, o que sugere que em doses maiores pode estar ocorrendo a repolimerização da celulose. Estes resultados serão averiguados em trabalhos futuros.

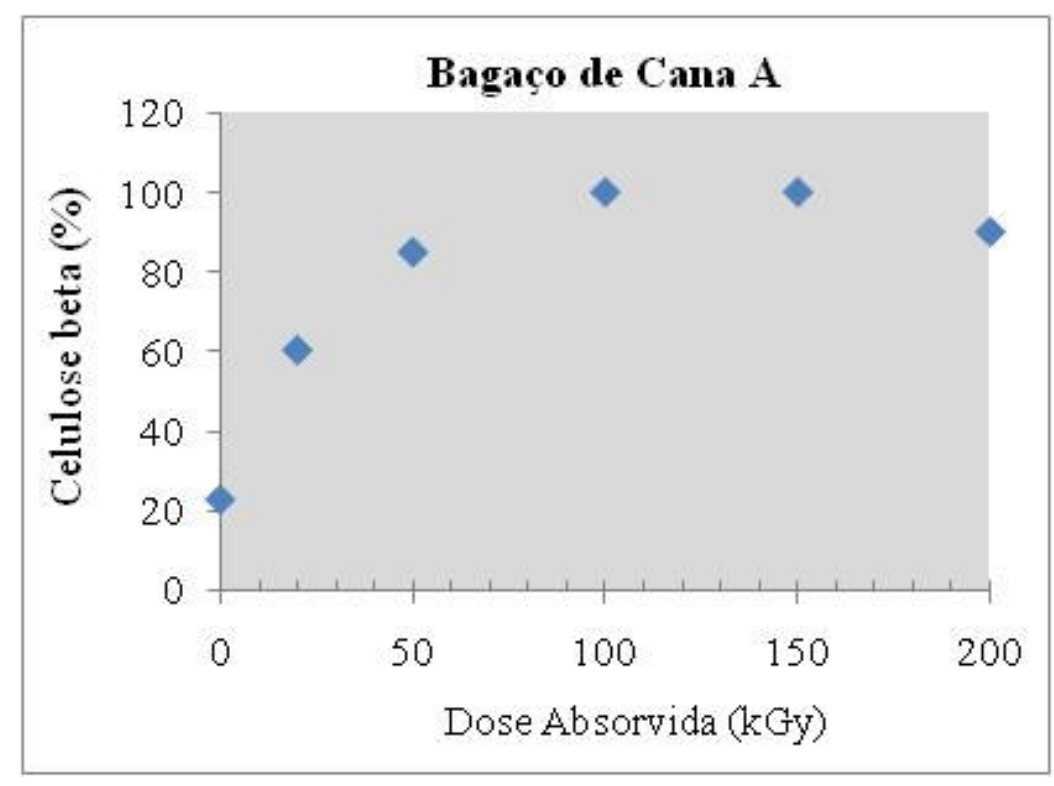

Figura 21. Variação do teor de celulose beta na amostra de Bagaço A após irradiação em diferentes doses absorvidas 


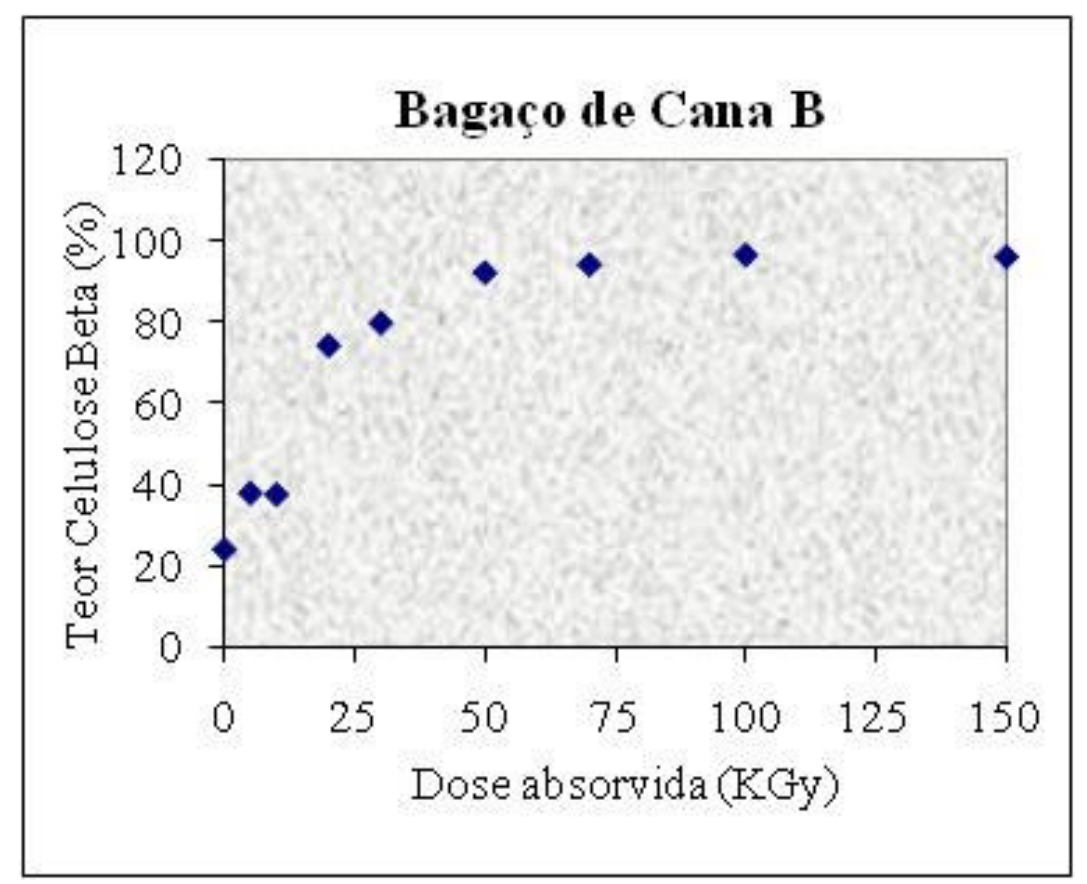

Figura 22. Variação do teor de celulose beta na amostra de Bagaço B após irradiação em diferentes doses absorvidas
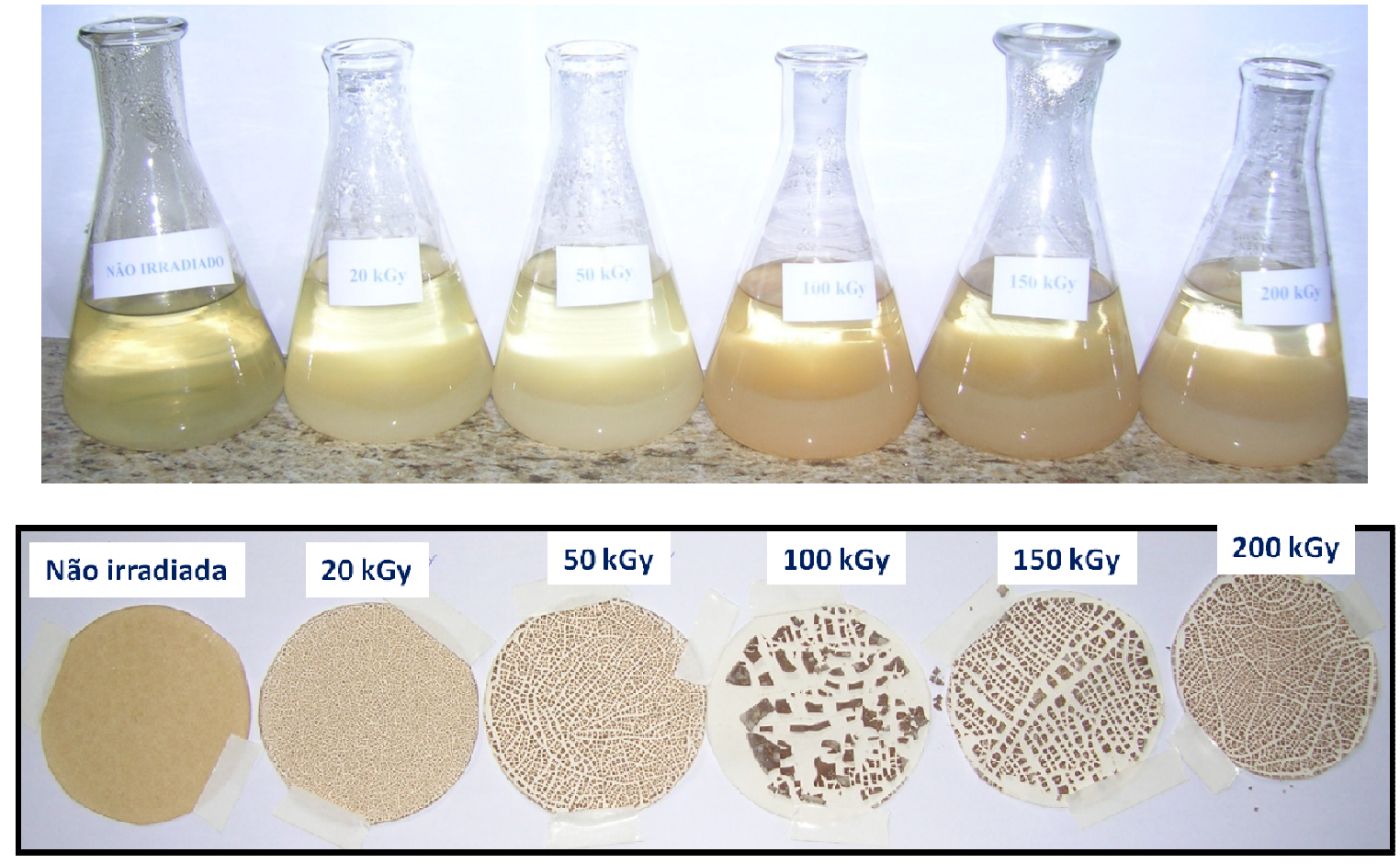

Figura 23. Alterações visuais no precipitado de celulose beta na amostra de Bagaço A após irradiação em diferentes doses absorvidas 


\subsubsection{Espectroscopia do Infravermelho}

A maior dificuldade para as análises de espectroscopia IV foi a preparação das amostras de bagaço com $\mathrm{KBr}$. Os resultados melhores de espectros foram obtidos com a mistura na proporção de 50,0 mg de $\mathrm{KBr}$ para $1,0 \mathrm{mg}(\mathrm{m} / \mathrm{m})$ de bagaço de cana.

$\mathrm{Na}$ Figura 24 são apresentados os espectros de transmitância obtidos para a amostra de Bagaço B não irradiado e irradiado com as doses de 5 kGy, 10 kGy, 70 kGy e 100 kGy. Na amostra não irradiada não foi possível a identificação de picos, mas nas irradiadas foram identificados o pico de absorção $3350 \mathrm{~cm}^{-1}$, que corresponde a grupos hidroxilas presentes na molécula, pico $2927 \mathrm{~cm}^{-1}$ que corresponde às ligações $\mathrm{C}-\mathrm{H}$, o pico $1732 \mathrm{~cm}^{-1}$ que caracteriza a carbonila $\mathrm{C}=\mathrm{O}$ e pico $1045 \mathrm{~cm}^{-1}$ que caracteriza as ligações C-O-C. A presença de molécula de água é confirmada através do pico 1592 $\mathrm{cm}^{-1}$. De acordo com a literatura (Liu et al., 2006; Fengel and Wegener, 1989, Xu, 2005) esses picos se encontram dentro da faixa de referência, para caracterização da molécula de celulose e aumentaram com a dose de radiação aplicada demonstrando a cisão da celulose.

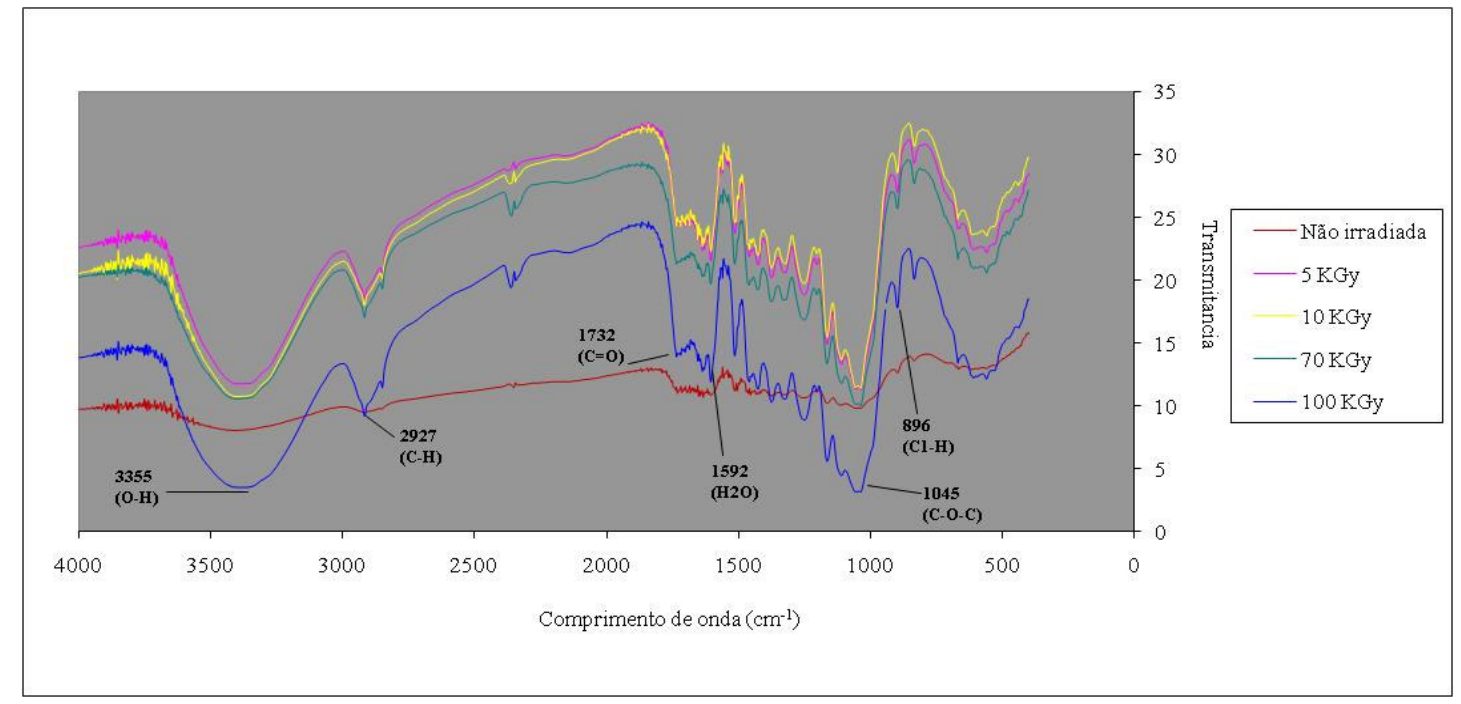

Figura 24. Espectros no infravermelho do Bagaço B antes e após irradiação em diferentes doses absorvidas com as identificações das principais funções orgânicas correspondentes à estrutura da celulose 


\subsubsection{Microscopia eletrônica}

A microscopia eletrônica da amostra do Bagaço B foi obtida para verificar as mudanças estruturais visíveis no material, causadas pela radiação ionizante. As fotos de microscopia eletrônica da amostra não irradiada e irradiadas com doses absorvidas de 10 kGy e 50 kGy são apresentadas na Figura 25. A amostra não irradiada apresentou fibras ordenadas e homogêneas enquanto que, após a irradiação, pode ser observado a presença de clivagens na camada externa, principalmente no bagaço de cana irradiado com 50 kGy.

Essa clivagem parcial na parede externa das amostras causada pela radiação ionizante aumenta a acessibilidade do substrato, que no caso é a celulose, para as enzimas. Porque a hidrólise enzimática requer um contato físico direto entre enzima e substrato, enzimas necessitam se difundir de uma solução aquosa para a superfície da partícula, difundindo através de barreiras físicas tais como a lignina, adsorvendo sobre a superfície do substrato para, então, catalisar a hidrólise.

\subsection{Efeitos do processamento por feixe de elétrons na hidrólise enzimática}

Os ensaios de hidrólise enzimática foram realizados apenas com a amostra de Bagaço B, coletada em abril/2008. Este ensaio avaliou quanto da celulose contida no bagaço de cana foi convertido em glicose pela enzima.

Na Tabela 3 são apresentados os resultados de massa de glicose obtida após hidrólise enzimática do Bagaço de cana B após 24 e 48 horas nas doses aplicadas e na Tabela 4 são apresentados os resultados de taxa de conversão e ganho após hidrólise enzimática após 14 e 48 horas nas doses aplicadas. 

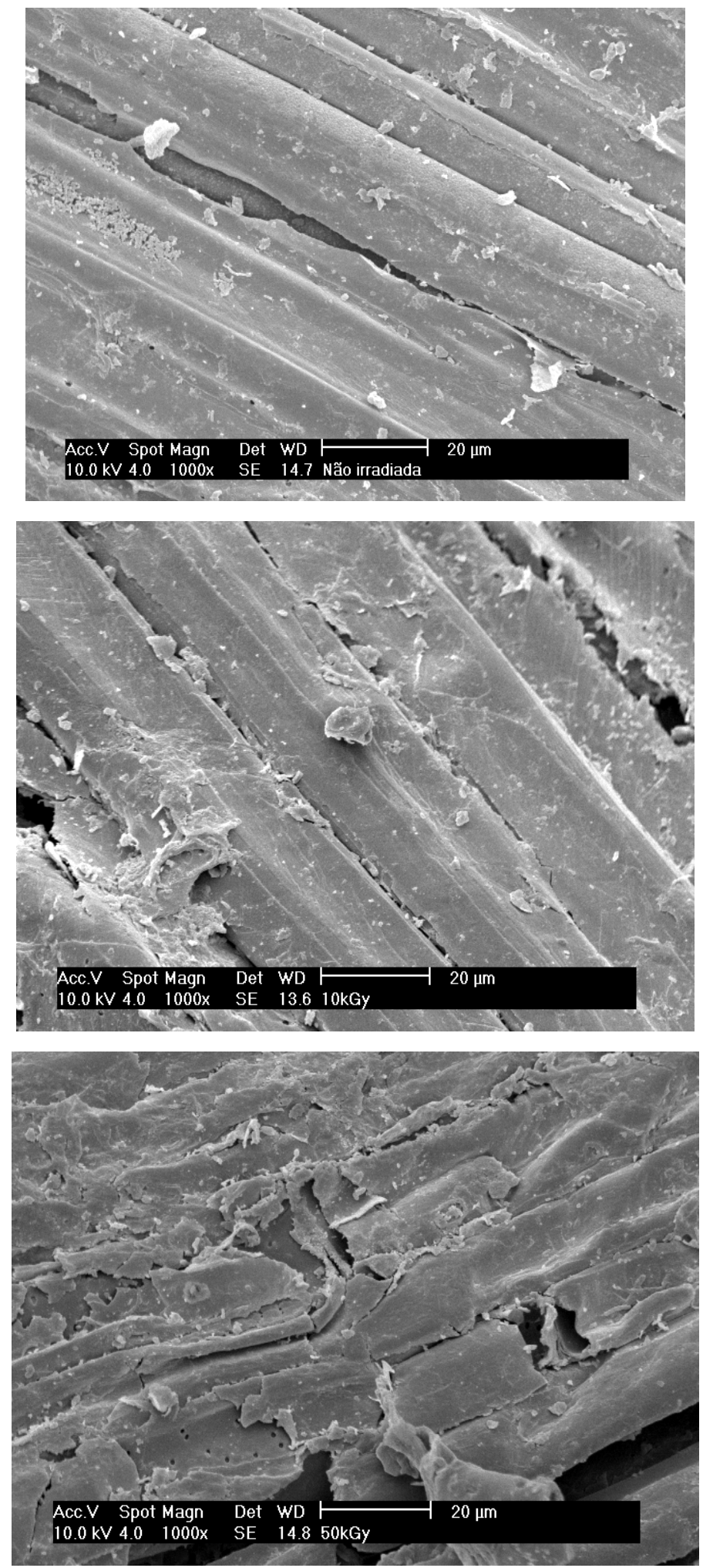

FIGURA 25 Micrografia eletrônica da amostra de Bagaço B não irradiado e irradiado com doses absorvidas de $10 \mathrm{kGy}$ e $50 \mathrm{kGy}$ 
Tabela 3. Massa de glicose obtida após hidrólise enzimática do Bagaço B em 24 e 48 horas nas doses aplicadas

\begin{tabular}{ccccc}
\hline \multirow{2}{*}{ Amostra } & \multicolumn{4}{c}{ Tempo = 24hs } \\
\cline { 2 - 5 } & $\begin{array}{c}\mathbf{1} \mathbf{A b s} \\
\mathbf{( 5 0 5 n m )}\end{array}$ & Diluição & $\begin{array}{c}\mathbf{C}_{\text {glicose }} \\
(\mathbf{g} / \mathbf{L})\end{array}$ & $\mathbf{M}_{\text {glicose }}$ (g) \\
\hline Não-Irradiado & 0,888 & 1 & 3,180 & 0,159 \\
$\mathbf{5 K G y}$ & 0,946 & 1 & 3,386 & 0,169 \\
$\mathbf{1 0 K G y}$ & 1,222 & 1 & 4,375 & 0,219 \\
$\mathbf{2 0 K G y}$ & 1,521 & 1 & 5,445 & 0,272 \\
$\mathbf{3 0 K G y}$ & 1,540 & 1 & 5,513 & 0,276 \\
$\mathbf{5 0 K G y}$ & 1,430 & 1 & 5,119 & 0,256 \\
$\mathbf{7 0 K G y}$ & 1,384 & 1 & 4,954 & 0,248 \\
$\mathbf{1 0 0 K G y}$ & 1,225 & 1 & 4,385 & 0,219 \\
$\mathbf{1 5 0 K G y}$ & 1,091 & 1 & 3,904 & 0,195 \\
\hline
\end{tabular}

\begin{tabular}{ccccc}
\hline \multirow{2}{*}{ Amostra } & \multicolumn{4}{c}{ Tempo $=\mathbf{4 8 h s}$} \\
\cline { 2 - 5 } & Abs (505nm) & Diluição & $\begin{array}{c}\mathbf{C}_{\text {glicose }} \\
(\mathbf{g} / \mathbf{L})\end{array}$ & $\mathbf{M}_{\text {glicose }}(\mathbf{g})$ \\
\hline Não-Irradiado & 0,030 & 30 & 3,186 & 0,159 \\
5KGy & 0,035 & 30 & 3,759 & 0,188 \\
10KGy & 0,045 & 30 & 4,832 & 0,242 \\
20KGy & 0,052 & 30 & 5,584 & 0,279 \\
30KGy & 0,053 & 30 & 5,692 & 0,285 \\
50KGy & 0,050 & 30 & 5,369 & 0,268 \\
70KGy & 0,049 & 30 & 5,262 & 0,263 \\
100KGy & 0,045 & 30 & 4,797 & 0,240 \\
150KGy & 0,038 & 30 & 4,081 & 0,204 \\
\hline${ }^{1}$ Dados de experimentos realizados em triplicata.
\end{tabular}


Tabela 4. Taxa de conversão e ganho após hidrólise enzimática do Bagaço B em 24 e 48 horas nas doses aplicadas

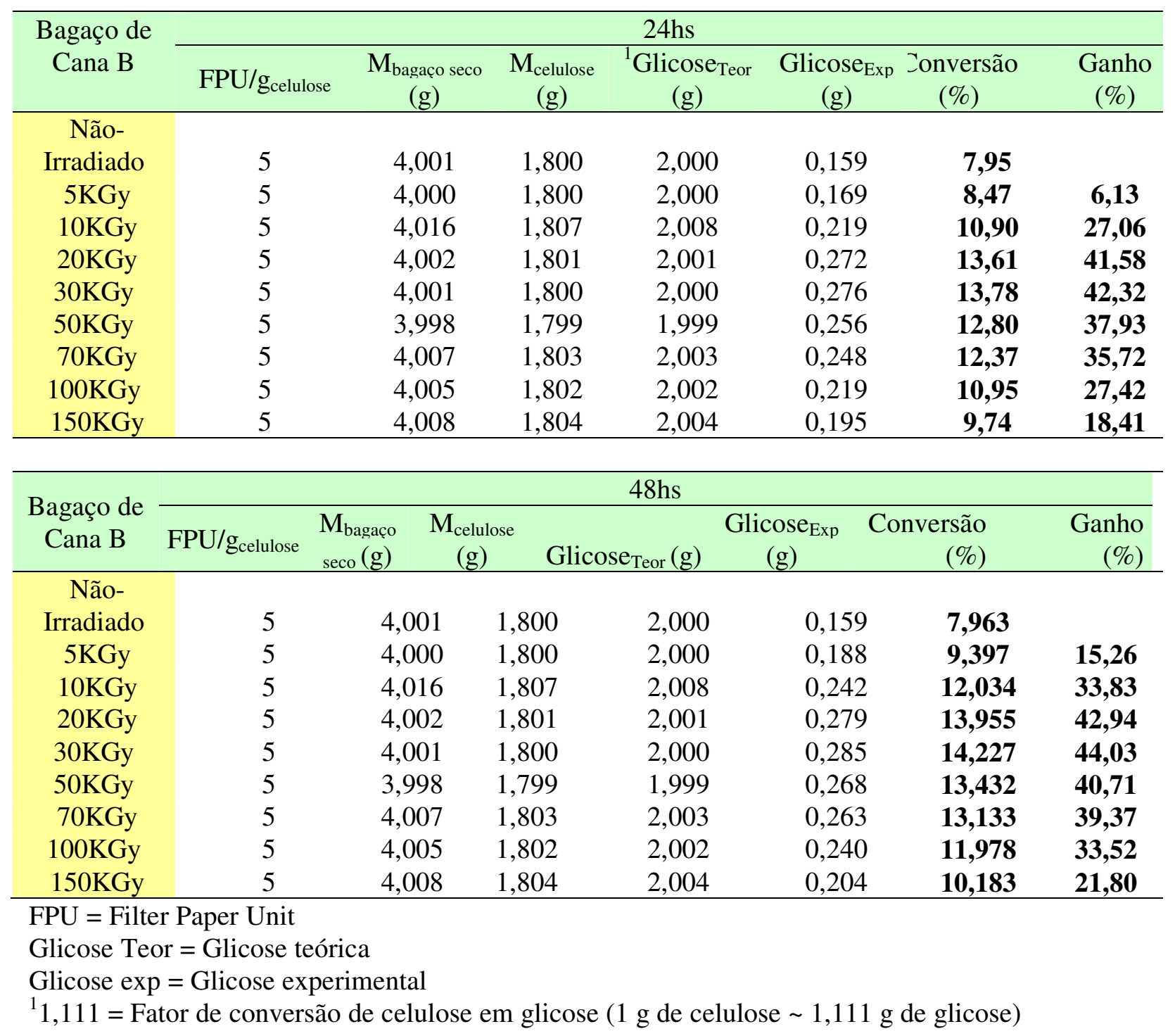

Com esses resultados foi construído o gráfico apresentado na Figura 26. Após a irradiação, houve um aumento no teor de glicose, tanto para o tempo de incubação de 24 horas como para 48 horas com uma dose absorvida de $30 \mathrm{kGy}$, a partir desta dose houve uma redução significativa no teor de glicose. Uma explicação para esse fato pode ser a degradação da 
glicose livre a partir de 30 kGy e/ou a inibição da enzima por substâncias liberadas pela degradação da lignina.

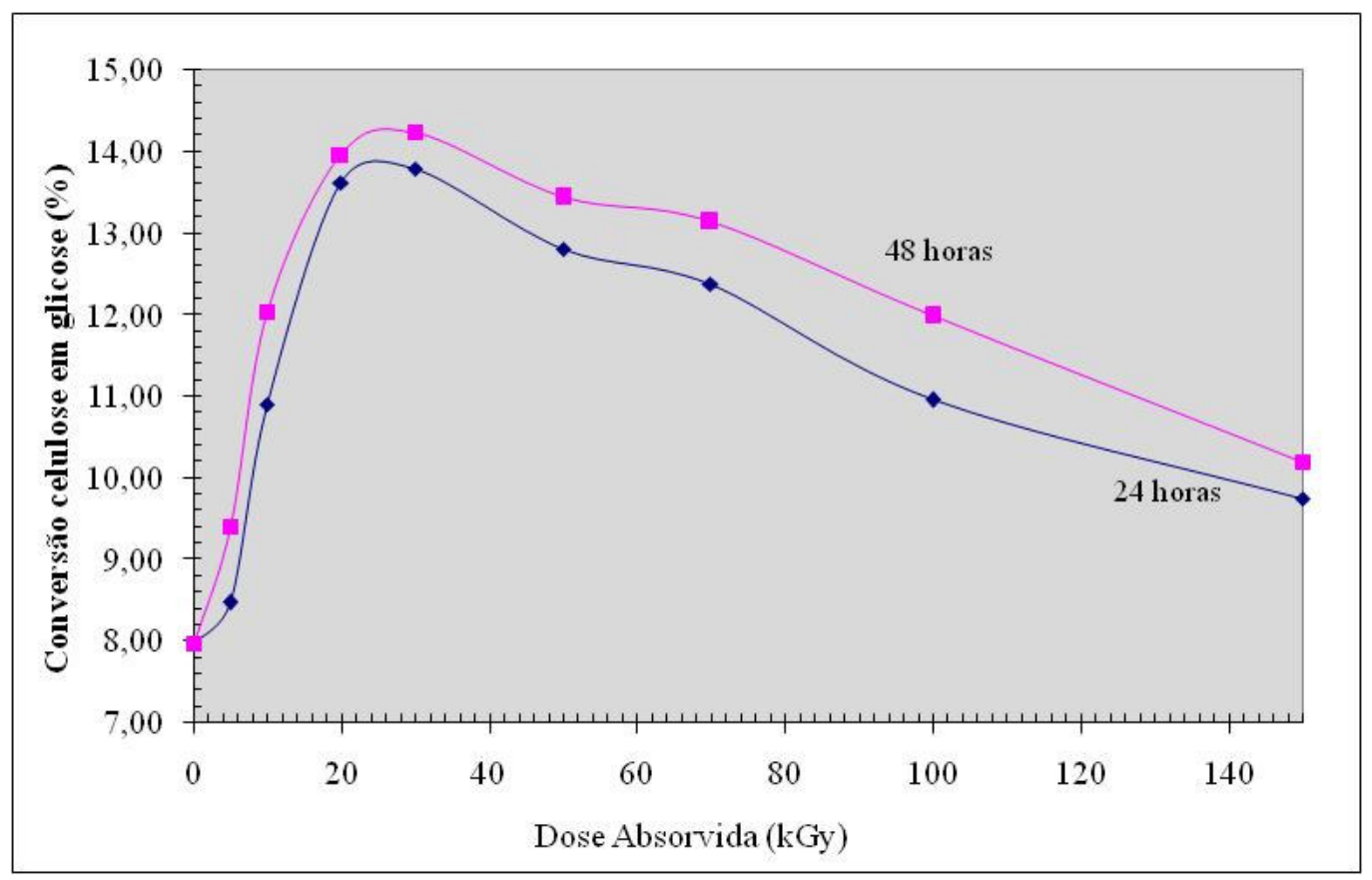

Figura 26. Conversão de celulose em glicose pela enzima após 24h e 48h no Bagaço B após irradiação em diferentes doses absorvidas

Segundo a literatura, durante a sacarificação de polissacarídeos são formados ácidos alifáticos como acético, fórmico e levulínico e derivados de furanos como o furfural e o 5-hidroxi metil furfural, $\mathrm{HMF}$, além de compostos fenólicos. Estes compostos podem inibir seriamente a hidrólise de celulose e fermentação dos açúcares numa etapa posterior de obtenção de etanol. Estes compostos podem ter sido os responsáveis pela inibição da atividade enzimática a partir da irradiação com cerca de 30 kGy, principalmente pelos compostos fenólicos liberados pela clivagem da lignina.

Ainda considerando a Figura 26, observa-se uma mudança com diminuição na tendência de queda da atividade enzimática a partir de cerca de 40kGy, que pode ter sido causada pela degradação dos compostos tóxicos formados pela ação da radiação. Um exemplo é a liberação do fenol 
apresentados nas Figuras 13 e 14. Trabalhos anteriores demonstram a eficiência da radiação ionizante na degradação de compostos orgânicos em diferentes matrizes (Duarte, 1999). Mais estudos serão realizados em trabalhos futuros para identificação mais precisa desses compostos e confirmação dessa suposição.

Uma dose de $20 \mathrm{kGy}$ aumentou o rendimento de conversão de celulose em glicose de cerca de $8 \%$ para cerca de $14 \%$, representando um aumento de cerca de 75\% na eficiência. Mesmo no caso das doses maiores, o rendimento foi maior do que a amostra não irradiada, chegando ao mínimo de cerca de $10 \%$ para uma dose absorvida de $150 \mathrm{kGy}$. 


\subsection{CONCLUSÕES}

O processamento com feixe de elétrons levou a alterações na estrutura e na composição do bagaço de cana, foi responsável pela clivagem parcial da lignina, em doses absorvidas relativamente baixas e que, embora essa clivagem tenha sido pouco significativa em termos de redução da lignina, foi suficiente para que a radiação interagisse tanto na hemicelulose como na celulose. Essa ação foi comprovada pela liberação dos açúcares, pela redução na celulose de alto peso molecular e também pelo aumento da celulose degradada;

A radiação facilitou a ação da enzima na hidrólise da celulose, mas em doses elevadas maiores que $20 \mathrm{kGy}$ houve uma redução na eficiência que pode ter sido causada pela liberação de compostos orgânicos inibidores e estes compostos também podem ter sofrido a ação da radiação em doses maiores.

O tempo de estocagem do bagaço não alterou os resultados significativamente, considerando que os resultados apresentados pela primeira amostragem, que correspondia a um bagaço de cana mais antigo e mais seco, foram similares aos obtidos para o bagaço recém moído e com umidade mais elevada;

Os efeitos da radiação obtidos neste trabalho ocorreram em doses absorvidas muito inferiores aos da literatura e isso se deve, principalmente, à manutenção da umidade natural presente no bagaço que ajuda na formação de radicais livres, potencializando a ação. 


\section{REFERÊNCIAS BIBLIOGRÁFICAS}

AMERICAN SOCIETY FOR TESTING AND MATERIALS. Standard test method for 1\% sodium hydroxide solubility of wood. United States: ASTM, 1995. (ASTM D 1109).

AMERICAN SOCIETY FOR TESTING AND MATERIALS. Standard test method for water solubility of wood. United States: ASTM, 1995. (ASTM D 1110).

AMERICAN SOCIETY OF CIVIL ENGINEERS. Radiation energy treatment of water, wastewater and sludge. A State-of-the-Art Report. NewYork, New York, 1992. P.30-34.

ASSOCIAÇÃO BRASILEIRA DE NORMAS TÉCNICAS. Pastas celulósicas - Determinação de celuloses alfa, beta e gama. Rio de Janeiro: ABNT, 1998. (NBR 14032).

BLY, J.H. Electron Beam Processing, Yardley, Pennsylvania, 1988.

BOURNE JUNIOR, J. K. O sonho verde. National Geografic Brasil, São Paulo, n.91, p.56, 2007.

BRENNER, W.; RUGG, B.; ARNON, J. Radiation pretreatments for optimizing the sugar yield in the acid hydrolysis of waste cellulose. Radiation Physics and Chemistry, v.14, p.299-308, 1979.

BROWNING, B.L. Methods of wood chemistry, v.2, New York, Interscience Publishers, 1967.

COPERSUCAR. Cana-de-açúcar. Disponível em: http://www.copersucar.com.br/institucional/por/academia/cana_acucar.asp. Acesso em 01/10/2007.

DUARTE, C. L. Aplicação do processo avançado de oxidação por feixe de elétrons na degradação de compostos orgânicos presentes em efluentes industriais. 1999. Tese (Doutorado) - Instituto de Pesquisas Energéticas e Nucleares, São Paulo. 
DUARTE, C. L.; GERALDO, L. L.; P. JUNIOR, O. A.; BORRELY, S. I.; SATO, I. M.; SAMPA, M. H. O. Treatment of effluents from petroleum production by electron beam irradiation. Radiation Physics and Chemistry, v.71, n.1, p.445-459, 2004.

DUARTE, C. L.; SAMPA, M. H. O.; RELA, P. R.; OIKAWA, H.; SILVEIRA, C. G. Advanced oxidation process by electron-beam-irradiation induced decomposition of pollutants in industrial effluents. Radiation Physics and Chemistry, v.63, n.3, p.647-651, 2002.

DUARTE, C. L.; OIKAWA, H.; MORI, M. N.; SAMPA, M. H. O. Present status of environmental application of electron beam accelerator in Brazil. In: International Symposium on Utilization of Accelerators, Viena, International Energy Agency, p.1-8, 2006.

DUBEY, K. A.; PUJARI, P. K.; RAMNANI, S. P.; KADAM R. M.; SABHARWAL, S. Microstructural studies of electron beam-irradiated cellulose pulp. Radiation Physics and Chemistry, v.69, p.395-400, 2004.

DZIEDZIELA, W. M.; KOTYNSKA, D. J. Functional groups in $\gamma$ irradiated cellulose. Radiation Physics and Chemistry, v.23, n.6, p.723-725, 1984.

ELLIOTT, A. Infra-red spectra and structure. London, Edward Arnold (Publishers) Ltd., 1969.

ERENO, D. Álcool de Celulose. Pesquisa Fapesp, 133, p. 29-31, 2007.

FOLDVÁRY, Cs.M; TAKÁCS, E.; WOJNÁROVITS, L. Effect of highenergy radiation and alkali treatment on the properties of cellulose. Radiation Physics and Chemistry, v.67, p.505-508, 2003.

FENGEL, D.; WEGENER, G. Wood - Chemistry, Ultrastructure, Reactions. New York, Walter de Gruyter, Inc., 1989.

GABRIELLI, I.; GATENHOLM, P.; GLASSER, W.G.; JAIN, R.K.; KENNE, L. Separation, characterization and hydrogel-formation of hemicellulose from aspen wood. Carbohydrate Polymers, v.43, p.367-374, 2000.

GETOFF, N. Radiation-induced degradation of water pollutants - state of the art. Radiation Physics and Chemistry, v.47, n.4, p.581-593, 1986. 
GLASSER, W. G.; KELLY, S. S. Encyclopedia of Polymer Science and Engeneering. New York, Jonh Wiley \& Sons, Inc. Lignin. p.796-849, 1987.

HAN, Y.W.; CATALANO, E.A.; CIEGLER, A. Chemical and physical properties of sugarcane bagasse irradiated with $\gamma$ rays. Journal of Agricultural and Food Chemistry, v.311, p.34-38, 1983.

HASSUANI, S. J. Biomass power generation: sugar cane bagasse and trash/Suleiman José Hassuani, Manoel Regis Lima Verde Leal, Isaías de Carvalho Macedo - Piracicaba: PNUD-CTC, 2005. p.217. (Série Caminhos para Sustentabilidade).

HIGA, O. Z.; DEL MAESTRO, N. L.; CASTAGNET, A. C. Immobilization of cellulase and cellobiase by radiation-induced polymerization. Radiation Physics and Chemistry, v.27, n.4, p.311-316, 1986.

KHAN, F.; AHMAD. S. R.; KRONFLI, E. $\gamma$ Radiation induced changes in the physical and chemical properties of lignocellulose. Biomacromolecules, v.7, p.2303-2309, 2006.

KOENIG, L. J. Spectroscopy of Polymers. $2^{\circ}$ ed. New York, Elsevier Science Inc., 1999.

KUMAKURA, M; KAETSU, I. Radiation-induced degradation and subsequent hydrolysis of waste cellulose materials. I. Journal of Applied Radiation and Isotopes, v.30, p.139-141, 1978.

LEONHARDT, J.W.; HENNING, A.; NEHRING, K.; BAR, M.; FLACHOWSKY, G.; WOLF, I. Gamma and electron radiation effects on agricultural by-products with high fibre content. In: INTERNATIONAL ATOMIC ENERGY AGENCY. Nuclear techniques for assessing and improving ruminant feed: proceedings...Vienna, 1983. p.195-202.

LEPIFRE, S.; FROMENT, M.; CASAUX, F. ; HOUOT, S. ; LOURDIN, D . ; COQUERET, X. ; LAPIERRE, C. ; BAUMBERGER, S. Lignin Incorporation combined with electron-beam irradiation improves the surface water resistance of starch films. Biomacromolecules, v.5, p.1678-1686, 2004.

LIU, C.; REN, J.; XU, F.; LIU, J.; SUN, J., SUN, R. Isolation and characterization of cellulose obtained from ultrasonic irradiated sugarcane 
bagasse. Journal of Agricultural and Food Chemistry, v.54, p.5742-5748, 2006.

MARTIN, C.; GALBE, M.; WAHLBOM, C.F.; HAGERDAL, B. H.; JONSSON, L. F. Ethanol production from enzymatic hydrolysates of sugarcane bagasse using recombinant xylose-utilising Saccharomyces cerevisia. Enzyme and Microbial Technology, v.31, p.274-282, 2002.

MORI, M. N.; SAMPA, M. H. O.; DUARTE, C. L. Study of the degradation of chlorpyrifos by ionizing radiation. Journal Radioanaytical and Nuclear Chemistry, v.270, n.1, p.99-102, 2006.

MORRISON, I.M. Improvements in the acetyl bromide technique to determine lignin and digestibility and its application to legumes. Journal of the Science of Food and Agriculture, v.23, p.1463-1469, 1972.

MOSIER, N. WYMAN,C. DALE, B.; ELANDER, R.; LEE, Y.Y.; HOLTZAPPLE, M.; LADISCH, M. Features of promising technologies for pretreatmentof lignocellulosic biomass. Bioresource Technology, v.96, p.673-686, 2005.

MUSSATTO, S. I.; FERNANDES, M.; MILAGRES, A.M.F.; ROBERTO, I. C. Effect of hemicellulose and lignin on enzymatic hydrolysis of cellulose from brewer's spent grain. Enzyme and Microbial Technology, v.43, p.124129, 2008.

PETROBRAS - Segunda geração de biocombustíveis: Petrobras desenvolve tecnologia. Disponível em: www.petrobras.br Acesso em 26/10/2007.

PIKAEV, A.K. Current state of radiation processing. Russian Chemistry Review, v.64, n.6, p.569-598, 1995.

PROCESSO DHR. Revista Química e Derivados. Disponível em: www.quimica.com.br/revista/qd417/alcool4.htm Acesso em 02/10/2007.

REYES, J.; ZAMORA, P.P.; DURAN, N. Hidrólise enzimática de casca de arroz utilizando-se celulases. Efeito de tratamentos químicos e fotoquímicos. Quimica Nova, v.21, n.2, p.140-143, 1998.

SUN, J. X.; SUN, X. F.; ZHAO, H.; SUN, R. C. Isolation and characterization of cellulose from sugarcane bagasse. Polymer Degradation and Stability, v.84, p.331-339, 2004. 
TAKÁCS, E.; WOJNÁROVITS, L.; FOLDVÁRY, Cs.; HARGITTAI, P.; BORSA, J.; SAJÓ, I. Effect of combined gamma-irradiation and alkali treatment on cotton-cellulose. Radiation Physics and Chemistry, v.57, p.399-403, 2000.

TAKÁCS， E.; WOJNÁROVITS， L.; BORSA， J.; FOLDVÁRY， Cs.; HARGITTAI, P.; ZOLD, O. Effect of $\gamma$ irradiated on cotton-cellulose. Radiation Physics and Chemistry, v.55, p.663-666, 1999.

THOMSON, C.I.; LOWE. R. M.; RAGAUSKAS A. J. Imaging cellulose fibre with interfaces with fluorescence microscopy and resonance energy transfer. Carbohydrate Polymers, v.69, p.799-804, 2007.

TSUJIYAMA, S; MIYAMORI, A. Assignment of DSC thermograms of wood and its components. Thermochimica Acta, v. 351, p. 177-181, 2000.

VITTI, D. M. S. S.; DEL MASTRO, N. L.; KIKUCHI, O. K.; NOGUEIRA, N. L. Irradiação de resíduos fibrosos com feixe de elétrons: efeitos na composição química e digestibilidade. Scientia Agrícola, v.55, n.2, p.159$171,1998$.

WAITE, T.D.; KRUGER, P.; KRUGER, P.; BRYAN, E.; SWINWOOD, J. F. Irradiation treatment of water and wastes. In: IAEA. Applications of isotopes and radiation in conservation of the environment : proceedings of symposium on..., held in Karlsruhe, 9-13 March, 1992. Viena, AIEA, 1992. p.143-152.

WANG, T.; WAITE, T.D.; KURUCZ, C.; COOPER, W.J. Oxidant reduction and biodegradability improvement of paper mill effluent by irradiation. Water Research, v.28, n.1, p.237-241, 1994.

WHISTHER R.L. Methods in Carbohydrate Chemistry. Vol.III. London, Academic Press Inc. Ltd., 1963.

WOOD, R.J. Radiation chemistry and its application to environment pollution. In: COOPER, J.C.; CURRY, R.D.; O'SHEA, K.E. eds. Environmental Applications of Ionizing Radiation. New York, Jonh Wiley \& Sons, Inc., 1998. p. 1-32.

XU, F.; SUN, J. X.; LIU, C .F.; SUN, R. C. Comparative study of alkali- and acidic organic solvent-soluble hemicellulosic polysaccharides from sugarcane bagasse. Carbohydrate Research, v.341, p.253-261, 2006. 